\title{
Nutrient demand interacts with grass particle length to affect digestion responses and chewing activity in dairy cows
}

\author{
K. L. Kammes and M. S. Allen ${ }^{1}$ \\ Department of Animal Science, Michigan State University, East Lansing 48824-1225
}

\begin{abstract}
Effects of grass particle length on dry matter intake (DMI), milk production, ruminal fermentation and pool sizes, digestion and passage kinetics, and chewing activity and the relationship of these effects with preliminary DMI (pDMI) were evaluated using 15 ruminally and duodenally cannulated Holstein cows in a crossover design with a 14-d preliminary period and two 18-d treatment periods. During the preliminary period, pDMI of individual cows ranged from 22.6 to $29.8 \mathrm{~kg} / \mathrm{d}($ mean $=25.8 \mathrm{~kg} / \mathrm{d})$ and $3.5 \%$ fat-corrected milk yield ranged from 29.2 to $56.9 \mathrm{~kg} / \mathrm{d}$ (mean $=41.9$ $\mathrm{kg} / \mathrm{d}$ ). Experimental treatments were diets containing orchardgrass silage chopped to either (a) 19-mm (long) or (b) 10-mm (short) theoretical length of cut as the sole forage. Grass silages contained approximately $46 \%$ neutral detergent fiber (NDF); diets contained $50 \%$ forage, $23 \%$ forage NDF, and $28 \%$ total NDF. Preliminary DMI, an index of nutrient demand, was determined during the last $4 \mathrm{~d}$ of the preliminary period when cows were fed a common diet and used as a covariate. Main effects of grass particle length and their interaction with pDMI were tested by ANOVA. Grass particle length and its interaction with $\mathrm{pDMI}$ did not affect milk yield, milk composition, or rumen $\mathrm{pH}$. Long particle length tended to decrease DMI compared with short particle length, which might have been limited by rumen fill or chewing time, or both. Passage rates of feed fractions did not differ between long and short particle lengths and were not related to level of intake. As pDMI increased, long particles decreased ruminal digestion rate of potentially digestible NDF at a faster rate than short particles. As a result, long particles decreased or tended to decrease rates of ruminal turnover for NDF, organic matter, and dry matter and increased their rumen pools compared with short particles for cows with high pDMI. Long particles increased eating time, which affected cows with high intake to the greatest extent, and total chewing time compared with short
\end{abstract}

Received May 31, 2011.

Accepted October 18, 2011.

${ }^{1}$ Corresponding author: allenm@msu.edu particles. As intake increased, ruminal digestion $(\mathrm{kg} / \mathrm{d})$ and digestibility (\%) of starch decreased, rumen pool size of starch increased, and postruminal digestion and digestibility of starch increased quadratically. When grass silage was the only source of forage in the diet, increasing chop length from 10 to $19 \mathrm{~mm}$ tended to decrease DMI but did not negatively affect productivity of cows, which were fed adequate fiber.

Key words: particle size, grass silage, chewing activity, digestion kinetics

\section{INTRODUCTION}

Forage particle size affects various aspects of rumen function and digestion kinetics. Ruminal digesta passage rates decrease with increasing particle size due to greater retention time in the rumen (Dixon and Milligan, 1985) and mat formation by long forage particles, which increases digestibility of smaller particles (Grant, 1997). Greater ruminal distention caused by longer forage particles is more likely to affect passage rate and feed intake of lactating dairy cows when feed intake is limited by rumen fill. Decreasing particle size permits rapid removal of digesta from the rumen, allowing increased feed intake when intake is limited by distention, but digestibility is decreased and ruminal $\mathrm{pH}$ might be reduced for several reasons, including a reduction in buffer capacity of ruminal digesta mass, a decrease in rate of VFA absorption from decreased motility, and a decrease in salivary buffer secretion from decreased rumination.

Forage particle length (FPL) has been widely researched, but the effects of FPL on animal responses are inconsistent and inconclusive. Some of the inconsistency on responses to particle size may be due to forage type. Tafaj et al. (2007) reported that effects of forage particle size were less when corn silage was included in the TMR and greater for grass silage-based TMR. Furthermore, grasses and legumes differ in in vitro cell wall digestion rates (Smith et al., 1972; Robles et al. 1980) and anatomical structure and digestion characteristics affecting particle size reduction and passage (Allen and Mertens, 1988). These differences suggest consideration of forage family is necessary when evaluating the effects 
of particle size. Orchardgrass (OG; Dactylis glomerata L.) was selected as a representative cool-season grass for use in this experiment.

Besides dietary factors, another reason for inconsistent responses to FPL may be related to animal factors. Cows respond differently to treatments depending on their level of intake (Voelker Linton and Allen, 2008) and production (Oba and Allen, 1999). Because FPL and level of intake affect ruminal passage and digestion rates and, thus, digesta fill in the rumen, the response to effects of particle size and its relationship with intake level should be assessed to determine if responses to treatment vary among cows with a wide range in DMI. We hypothesized that responses of DMI and digesta passage rates to grass particle length are related to level of intake and shorter particle length will permit a greater increase in passage rate than longer particle length as feed intake increases.

The objectives of this experiment were to evaluate the relationships between voluntary DMI and effects of length of cut of grass silage on DMI, milk production, ruminal fermentation and pool sizes, digestion and passage kinetics, and chewing behavior in lactating dairy cows. This study had 3 unique features to improve our understanding of the role of particle size and interpret its effect on animal responses. First, it allowed effects of the interaction between FPL and preliminary DMI (pDMI) to be evaluated. The use of pDMI, an index of nutrient demand, allowed the evaluation of treatments on animal responses in relation to level of intake and provided an indicator to test effects of intake level independent of treatments. Second, it directly compared treatment effects of long- and short-cut OG as the sole source of forage without the confounding effects of other dietary factors. Third, ruminal passage rates of individual feed fractions, instead of entire feeds, were measured using ruminally and duodenally cannulated cows.

\section{MATERIALS AND METHODS}

\section{Cows and Treatments}

Experimental procedures were approved by the Institutional Animal Care and Use Committee at Michigan
State University (East Lansing). Fifteen multiparous Holstein cows from the Michigan State University Dairy Cattle Teaching and Research Center were assigned randomly to treatment sequence in a crossover design experiment with one 14-d preliminary period and two 18-d experimental periods. The first $10 \mathrm{~d}$ of each period were allowed for diet adaptation and samples were collected during the final $4 \mathrm{~d}$ of the preliminary period and $8 \mathrm{~d}$ of each experimental period. Cows were 164 \pm 56 (mean $\pm \mathrm{SD}$ ) DIM at the end of the preliminary period and were selected to provide a wide range and uniform distribution of pDMI and milk yield. During the final $4 \mathrm{~d}$ of the 14-d preliminary period, the average pDMI among cows ranged from 22.6 to $29.8 \mathrm{~kg} / \mathrm{d}$ (mean $=25.8 \mathrm{~kg} / \mathrm{d}$ ) and $3.5 \% \mathrm{FCM}$ yield ranged from 29.2 to $56.9 \mathrm{~kg} / \mathrm{d}($ mean $=41.9 \mathrm{~kg} / \mathrm{d}$; Table 1$)$. Prior to calving, cows were cannulated ruminally (Bar Diamond Inc., Parma, ID) and duodenally with a gutter-type $T$ cannula placed approximately $10 \mathrm{~cm}$ distal to the pylorus (Joy et al., 1997). Surgery was performed at the Department of Large Animal Clinical Science, College of Veterinary Medicine, Michigan State University.

Experimental treatments were diets containing OG silage chopped to either (a) $19 \mathrm{~mm}$ (long) or (b) $10 \mathrm{~mm}$ (short) theoretical length of cut (TLC) as the sole forage. These TLC were selected to provide a wide interval within the normal range of TLC to examine if animal response to FPL is affected by level of feed intake.

Orchardgrass (Baridana cultivar; Barenbrug USA, Tangent, OR) was produced at the campus farm at Michigan State University, chopped from the same field, and ensiled in Ag-Bags (Ag-Bag Systems Inc., St. Nazianz, WI). During the sample-collection periods, long- and short-cut OG contained approximately $46 \%$ NDF (DM basis; Table 2). Diets with long and short particle lengths were formulated to contain $21 \%$ forage NDF, $28 \%$ total NDF, and $18 \% \mathrm{CP}$. The diet fed during the preliminary period was formulated so that longand short-cut OG each contributed $50 \%$ of forage NDF. Diets also contained dry ground corn, soybean meal (48\% CP), SoyPLUS (West Central Soy Cooperative, Ralston, IA), vitamin-mineral premix, and limestone (Table 3).

Table 1. Characterization of 15 cows during the final $4 \mathrm{~d}$ of the 14-d preliminary period, when cows were fed a common diet

\begin{tabular}{lccccc}
\hline Parameter & Median & Mean & SD & Minimum & Maximum \\
\hline Parity & 3 & 3.1 & 1.2 & 2 & 6 \\
BW, ${ }^{1}$ kg & 581 & 579 & 58 & 469 & 687 \\
BCS & 2.1 & 2.3 & 0.7 & 1.5 & 3.7 \\
DIM & 168 & 164 & 56 & 83 & 24.2 \\
Milk, kg/d & 43.1 & 41.5 & 10.6 & 29.2 & 52.2 \\
$3.5 \% \mathrm{FCM}, \mathrm{kg} / \mathrm{d}$ & 40.6 & 41.9 & 8.9 & 22.6 & 29.8 \\
DMI, kg/d & 25.4 & 25.8 & 2.1 & \\
\hline
\end{tabular}

${ }^{1}$ Empty BW (ruminal digesta removed) 


\section{Data and Sample Collection}

Throughout the experiment, cows were housed in tie-stalls and fed diets as TMR once daily $(1130 \mathrm{~h})$ at $110 \%$ of expected intake. The amount of feed offered and refused (orts) was weighed daily for each cow. Forage samples were collected twice weekly and analyzed to adjust diets to account for DM, NDF, and CP fluctuation. Samples of all dietary ingredients $(0.5 \mathrm{~kg})$ and orts $(12.5 \%)$ were collected daily from d 11 to 14 during the preliminary period and d 11 to 15 during each experimental period. Samples were frozen immediately after collection at $-20^{\circ} \mathrm{C}$ and combined to 1 composite sample per period before analysis.

Cows were moved to an exercise lot twice daily (0230 and $1300 \mathrm{~h}$ ) before milking in a parlor (0400 and 1430 h). Milk yield was measured and milk was sampled at each milking on d 11 to 14 of the preliminary period and on d 11 to 15 of the experimental periods. Rumenempty BW was measured by weighing the cow after evacuation of ruminal digesta on d 14 of the preliminary period and d 18 of each experimental period. Body condition score was determined on the same days by 3 trained investigators blinded to treatments (Wildman et al., 1982; 5 -point scale where $1=$ thin and $5=$ fat). Chewing activity was monitored and recorded by observation every 5 min for $24 \mathrm{~h}$ on d 16 of each experimental period. Activity was noted as eating, ruminating, drinking, or idle for each cow at each time.

Duodenal samples $(900 \mathrm{~mL})$, fecal samples (500 $\mathrm{g})$, rumen fluid and particulate samples for microbial isolation (400 g), rumen fluid samples for $\mathrm{pH}$, and

Table 2. Chemical composition, particle size distribution, and fermentation parameters of the long- (19 $\mathrm{mm})$ and short-cut $(10 \mathrm{~mm})$ orchardgrass silage included in the treatment diets

\begin{tabular}{|c|c|c|}
\hline \multirow[b]{2}{*}{ Item } & \multicolumn{2}{|c|}{ Orchardgrass silage } \\
\hline & Long & Short \\
\hline \multicolumn{3}{|l|}{ Chemical composition } \\
\hline DM, \% & 26.5 & 31.4 \\
\hline OM, \% DM & 88.2 & 88.4 \\
\hline $\mathrm{NDF}, \% \mathrm{DM}$ & 46.9 & 45.2 \\
\hline iNDF, ${ }^{1} \% \mathrm{DM}$ & 12.2 & 11.6 \\
\hline iNDF, $\%$ of NDF & 26.1 & 25.7 \\
\hline $\mathrm{ADF}, \%$ of DM & 31.3 & 32.1 \\
\hline $\mathrm{ADL}, \%$ of DM & 4.42 & 4.57 \\
\hline $\mathrm{CP}, \% \mathrm{DM}$ & 21.1 & 20.5 \\
\hline Starch, \% DM & 1.21 & 1.24 \\
\hline \multicolumn{3}{|c|}{ Particle size distribution ${ }^{2}$} \\
\hline \multicolumn{3}{|c|}{ Wet sieving, \% DM retained } \\
\hline $19.0 \mathrm{~mm}$ & 30.6 & 27.1 \\
\hline $9.50 \mathrm{~mm}$ & 28.4 & 24.4 \\
\hline $4.75 \mathrm{~mm}$ & 15.5 & 28.1 \\
\hline $2.36 \mathrm{~mm}$ & 5.81 & 14.3 \\
\hline $1.18 \mathrm{~mm}$ & 3.24 & 4.57 \\
\hline $0.600 \mathrm{~mm}$ & 2.19 & 2.33 \\
\hline $0.300 \mathrm{~mm}$ & 1.09 & 1.41 \\
\hline $0.150 \mathrm{~mm}$ & 0.57 & 0.72 \\
\hline $0.075 \mathrm{~mm}$ & 0.34 & 0.37 \\
\hline $0.038 \mathrm{~mm}$ & 0.36 & 0.34 \\
\hline Mean particle size, ${ }^{3} \mathrm{~mm}$ & 15.3 & 11.3 \\
\hline \multicolumn{3}{|c|}{ Penn State Particle Separator, ${ }^{4} \%$ DM retained } \\
\hline$>19.0 \mathrm{~mm}$ & 46.1 & 26.2 \\
\hline 19.0 to $8.0 \mathrm{~mm}$ & 29.0 & 31.7 \\
\hline$<8.0 \mathrm{~mm}$ & 24.9 & 42.1 \\
\hline \multicolumn{3}{|l|}{ Fermentation } \\
\hline $\mathrm{pH}$ & 4.63 & 4.69 \\
\hline Acetic acid, \% DM & 3.36 & 5.26 \\
\hline Propionic acid, \% DM & 0.12 & 0.49 \\
\hline Butyric acid, \% DM & $<0.01$ & 0.09 \\
\hline Lactic acid, \% DM & 10.5 & 10.6 \\
\hline Lactic:acetic & 3.14 & 2.01 \\
\hline Ethanol, \% DM & 0.12 & 0.40 \\
\hline Ammonia, $\mathrm{m} M$ & 5.09 & 4.84 \\
\hline
\end{tabular}


Table 3. Ingredients and chemical composition of preliminary and treatment diets (as analyzed) containing either long- $(19 \mathrm{~mm})$ or short-cut $(10 \mathrm{~mm})$ orchardgrass silage as the sole source of forage

\begin{tabular}{lccc}
\hline Diet composition & Preliminary & Long & Short \\
\hline Ingredient, \% DM & & & \\
Orchardgrass silage, long cut & 26.0 & 49.8 & 49.7 \\
Orchardgrass silage, short cut & 26.0 & - & 37.9 \\
Dry ground corn & 36.9 & 38.4 & 3.45 \\
Soybean meal (48\% CP) & 1.99 & 2.89 & 3.39 \\
SoyPLUS ${ }^{1}$ & 3.47 & 3.39 & 1.60 \\
Vitamin mineral mix ${ }^{2}$ & 3.97 & 3.97 & 46.5 \\
Limestone & 1.60 & 1.60 & 90.1 \\
Chemical composition & & & 27.4 \\
DM, \% & 41.7 & 40.8 & 22.5 \\
OM, \% DM & 89.9 & 90.0 & 82.1 \\
NDF, \% DM & 28.5 & 28.3 & 7.90 \\
\% Forage NDF & 23.8 & 23.3 & 28.8 \\
\% NDF from forage & 83.4 & 82.6 & 8.20 \\
iNDF, \% DM & 6.25 & 29.0 & 29.5 \\
iNDF, \% of NDF & 21.9 & 17.9 & 29.8 \\
CP, \% DM & 17.1 & & \\
Starch, \% DM & 29.2 & & \\
\hline
\end{tabular}

${ }^{1}$ West Central Soy Cooperative, Ralston, IA.

${ }^{2}$ Vitamin mineral mix contained (DM basis) $16.5 \%$ sodium bicarbonate, $14.2 \%$ magnesium sulfate, $7.1 \%$ salt, $5.8 \%$ dicalcium phosphate, $2.4 \%$ trace mineral premix, $0.4 \%$ vitamin $\mathrm{A}, 0.4 \%$ vitamin $\mathrm{D}, 0.2 \%$ vitamin $\mathrm{E}$, and $53.1 \%$ dry ground corn as a carrier.

${ }^{3} \mathrm{iNDF}=$ indigestible NDF.

concentrations of VFA, lactate, and ammonia (100 $\mathrm{mL}$ ) were collected every $15 \mathrm{~h}$ from $\mathrm{d} 11$ to 15 of each experimental period so that 8 samples were taken for each cow in each period, representing every $3 \mathrm{~h}$ of a 24 -h period to account for diurnal variation. Rumen fluid and particulate matter for microbial isolation was collected from the reticulum near the reticular-omasal orifice, transported to the laboratory, and processed. Rumen fluid for $\mathrm{pH}$, VFA, lactate, and ammonia was obtained by combining digesta from 5 different sites in the rumen and straining it through nylon mesh $(\sim 1 \mathrm{~mm}$ pore size); fluid $\mathrm{pH}$ was recorded immediately. Samples were stored at $-20^{\circ} \mathrm{C}$.

Ruminal contents were evacuated manually through the ruminal cannula $4 \mathrm{~h}$ after feeding at the beginning of $\mathrm{d} 17(1530 \mathrm{~h})$ and $2 \mathrm{~h}$ before feeding at the end of d 18 (0930) for each experimental period. Total rumen content mass and volume were determined. To ensure accurate sampling, every tenth handful of digesta (10\%) was separated for a subsample throughout evacuation. This subsample was squeezed into primarily solid and liquid phases. Both phases were weighed and sampled $(350 \mathrm{~mL})$ for determination of nutrient pool size. All samples were stored at $-20^{\circ} \mathrm{C}$.

\section{Sample Analysis and Calculations}

Milk yield recorded at both milkings were summed for a daily total, which were averaged for each period. Milk samples were analyzed for fat, true protein, lactose,
SNF, and MUN with infrared spectroscopy by Michigan DHIA (East Lansing). Yields of 3.5\% FCM and milk components were calculated using milk yield and component concentrations for each milking, summed for a daily total, and averaged for each period.

Forage samples were combined to 1 composite sample per forage per period. Particle size distribution was determined using the Penn State Particle Separator containing 2 sieves (19 and $8 \mathrm{~mm}$ ) and a pan (Lammers et al., 1996). Due to the high moisture content of the silages, the particles tended to cling together and remain on the top sieve during the shaking process yielding inaccurate measurements. Therefore, samples were dried to a constant weight with forced air (no added heat) before separation. In addition, samples were wet sieved manually and sequentially through screens with the following aperture sizes: 19.0, 9.50, 4.75, 2.36, 1.18, $0.600,0.300,0.150,0.075$, and $0.038 \mathrm{~mm}$. The fraction of DM retained on the screens from wet sieving was used to calculate mean particle size.

Diet ingredients, orts, and feces were lyophilized (Tri-Philizer MP; FTS Systems Inc., Stone Ridge, NY). All dried samples were ground with a Wiley mill (1-mm screen; Arthur H. Thomas Co., Philadelphia, PA). Dried, ground fecal samples were combined on an equal DM basis into 1 sample per cow per period. Frozen duodenal samples for each cow period $(\mathrm{n}=8)$ were chopped finely using a commercial food processor (84142 Food cutter; Hobart Manufacturing Co., Troy, $\mathrm{OH})$ and subsampled in the frozen state to obtain rep- 
resentative samples. These duodenal subsamples and the $350 \mathrm{~mL}$ of ruminal solid and liquid samples were lyophilized and ground as described above. Dried ruminal solid and liquid samples were recombined according to the original ratio of solid and liquid DM.

Samples were analyzed for ash, NDF, indigestible NDF (iNDF), ADF, ADL, CP, and starch. Ash concentration was determined after $5 \mathrm{~h}$ combustion at $500^{\circ} \mathrm{C}$ in a muffle furnace. Concentrations of NDF were determined according to Mertens (2002) and ADF and ADL according to Goering and Van Soest (1970). Indigestible NDF was estimated as NDF residue after 240-h in vitro fermentation (Goering and Van Soest, 1970); flasks were reinoculated at $120 \mathrm{~h}$ to ensure a viable microbial population. Ruminal fluid for the in vitro incubations was collected from a nonpregnant dry cow fed dry hay only. Fraction of potentially digestible NDF (pdNDF) was calculated by difference (1.00 iNDF). Crude protein was analyzed according to Hach et al. (1987). Starch was measured by an enzymatic method (Karkalas, 1985) after samples were gelatinized with sodium hydroxide. Glucose concentration was measured using a glucose oxidase method (Glucose kit \#510; Sigma Chemical Co., St. Louis, MO), and absorbance was determined with a micro-plate reader (SpectraMax 190; Molecular Devices Corp., Sunnyvale, CA). Concentrations of all nutrients except DM were expressed as percentages of DM, determined by drying at $105^{\circ} \mathrm{C}$ in a forced-air oven for more than $8 \mathrm{~h}$.

Duodenal digesta were analyzed for purines and ammonia to estimate microbial $\mathrm{N}$ (MN) flow and nonammonia, nonmicrobial N (NANMN) flow to the duodenum. Purine concentration was used as a microbial marker, and purine-to-MN ratio was estimated by analysis of microbial pellets obtained by differential centrifugation of the rumen fluid and particulate samples collected near the reticulum. Rumen fluid and particulate matter was blended, strained through nylon mesh, and the liquid portion was centrifuged at $500 \times g$ for $15 \mathrm{~min}$. The supernatant was centrifuged at 18,000 $\times g$ for $15 \mathrm{~min}$, and the pellet was washed with $0.9 \%$ $\mathrm{NaCl}$ solution and centrifuged again at $18,000 \times g$ for 15 min, resuspended in water, and lyophilized. Total purines were measured by spectrophotometer (Beckman Instruments Inc., Fullerton, CA) at $260 \mathrm{~nm}$ according to Zinn and Owens (1986). Ammonia concentration was determined for centrifuged duodenal and rumen fluid samples according to Broderick and Kang (1980). Rumen fluid was also analyzed for concentration of major VFA and lactate by HPLC (Waters Corp., Milford, MA) according to Oba and Allen (2003a).

Dry matter and nutrient intakes were calculated using the composition of feed offered and refused. Ruminal pool sizes (kg) of OM, NDF, iNDF, pdNDF, starch,
MN, and NANMN were determined by multiplying the concentration of each component in rumen samples by the ruminal digesta DM mass $(\mathrm{kg})$. Duodenal flows $(\mathrm{kg} / \mathrm{d})$ of DM, OM, total NDF, pdNDF, starch, MN, NANMN, and ammonia $\mathrm{N}$ were determined using iNDF as a flow marker; iNDF intake $(\mathrm{kg} / \mathrm{d})$ was multiplied by the ratio between the component and iNDF in duodenal digesta. Duodenal flow of microbial OM was determined using the ratio of purines:OM (Oba and Allen, 2003a), and true ruminally digested OM was calculated by subtracting duodenal flow of nonmicrobial OM from OM intake. Indigestible NDF was used as an internal marker to estimate nutrient digestibility in the rumen and in the total tract (Cochran et al., 1986). Turnover rate in the rumen, passage rate from the rumen, and ruminal digestion rate of each component was calculated by the following equations:

$$
\text { turnover rate }(\% / \mathrm{h})=100 \times(\text { intake of component } /
$$$$
\text { ruminal pool of component)/24; }
$$

passage rate $(\% / \mathrm{h})=100 \times($ duodenal flow

of component/ruminal pool of component)/24;

digestion rate $(\% / \mathrm{h})=$ turnover rate in the rumen

$$
(\% / \mathrm{h}) \text { - passage rate from the rumen }(\% / \mathrm{h}) \text {. }
$$

Manually observed chewing activity was summarized by a logic script in Igor Pro (version 6.12; WaveMetrics Inc., Lake Oswego, OR) to generate meal and rumination bout information according to previously established criteria (Dado and Allen, 1994). Variables determined included frequency of meal bouts per day, interval between meals, frequency of ruminating bouts per day, interval between ruminating bouts, eating time per day, ruminating time per day, and total chewing time per day.

\section{Statistical Analysis}

All data were analyzed by using the fit model procedure of JMP (Version 8; SAS Institute Inc., Cary, $\mathrm{NC}$ ). To determine differences between treatments and evaluate interactions of treatment with DMI, where pDMI (calculated as the mean of DMI values on $d 11$ to 14 of the 14-d preliminary period) was used as the covariate for treatment responses, data were analyzed according to the following model: $\mathrm{Y}_{\mathrm{ijk}}=\mu+\mathrm{C}_{\mathrm{i}}+\mathrm{P}_{\mathrm{j}}+$ $\mathrm{T}_{\mathrm{k}}+\mathrm{PT}_{\mathrm{jk}}+\mathrm{pDMI}+\mathrm{T}_{\mathrm{k}} \mathrm{pDMI}+\mathrm{pDMI}^{2}+\mathrm{T}_{\mathrm{k}} \mathrm{pDMI}^{2}$ $+e_{i j k}$, where $Y_{i j k}$ is the dependent variable, $\mu$ is the overall mean, $\mathrm{C}_{\mathrm{i}}$ is the random effect of cow $(\mathrm{i}=1$ to 
15), $P_{j}$ is the fixed effect of period ( $\mathrm{j}=1$ to 2$), \mathrm{T}_{\mathrm{k}}$ is the fixed effect of treatment ( $\mathrm{k}=1$ to 2 ), $\mathrm{PT}_{\mathrm{jk}}$ is the interaction of period and treatment, $\mathrm{pDMI}$ is the linear effect of pDMI, $\mathrm{T}_{\mathrm{k}} \mathrm{pDMI}$ is the interaction of treatment and $\mathrm{pDMI}$ (linear), $\mathrm{pDMI}^{2}$ is the quadratic effect of $\mathrm{pDMI}, \mathrm{T}_{\mathrm{k}} \mathrm{pDMI}^{2}$ is the interaction of treatment and pDMI (quadratic), and $e_{\mathrm{ijk}}$ is the residual error. Statistical significance for $\mathrm{T}_{\mathrm{k}} \mathrm{pDMI}$ and $\mathrm{T}_{\mathrm{k}} \mathrm{pDMI}^{2}$ indicated treatment differences were related to pDMI. Covariate and interaction terms were removed stepwise from the model if $P>0.20$. Treatment effects and their interaction (linear and quadratic relationships) were declared significant at $P \leq 0.05$ and $P \leq 0.10$, respectively. Tendencies for treatment effects and their interactions were declared at $P \leq 0.10$ and $P \leq 0.15$, respectively.

Sixteen cows started the experiment; however, 1 cow went off feed during the second experimental period $2 \mathrm{~d}$ before the start of sample collection and was removed. Thus, data from 15 cows were statistically analyzed.

\section{RESULTS AND DISCUSSION}

\section{Comparison of Forages and Diets}

Physical characteristics of OG are listed in Table 2. Forages chopped to a TLC of 19 and $10 \mathrm{~mm}$ had mean particle sizes of 15.3 and $11.3 \mathrm{~mm}$, respectively. The proportion of particles $>19 \mathrm{~mm}$ was 20 percentage points higher (46 vs. $26 \%$ ) and the proportion of particles $<8 \mathrm{~mm}$ was 17 percentage points lower $(25$ vs. $42 \%$ ) for long- than short-cut OG, respectively. The particle size distribution of short-cut OG was similar to the guidelines recommended by Heinrichs (1996) that the portion of haylage retained on the $19-\mathrm{mm}$ sieve, the 8-mm sieve, and the bottom pan of the Penn State Particle Separator should be 15 to $25 \%, 30$ to $40 \%$, and 40 to $50 \%$, respectively.

Chemical analyses (Table 2) showed that OG with different lengths of cut had similar concentrations of $\mathrm{OM}$, total NDF, pdNDF, iNDF, ADF, ADL, CP, and starch. Both silages were wetter than expected and long-cut OG had lower DM concentration than shortcut OG due to the shorter wilting time for long-cut OG, as the silages were sequentially harvested and long-cut OG was mowed, chopped, and ensiled first. Both OG silages underwent favorable fermentation and were well preserved based on the low $\mathrm{pH}$ and high lactic acid concentrations. However, the concentrations of acetic acid were higher than that typical for grass silages, which is likely due to the high moisture content of both $\mathrm{OG}$ (Kung and Shaver, 2001).

Diet ingredients and chemical composition are shown in Table 3. The preliminary diet contained similar proportions of forage NDF from long- and short-cut OG. Both treatment diets had a 50:50 forage:concentrate ratio, contained $23 \%$ forage NDF, and had similar chemical composition, which was calculated according to the proportion of each feed ingredient in the diet and its respective analytical values. The calculated percent forage NDF in the diet was slightly higher than the formulated target but was similar for both long and short particles and above NRC (2001) minimum require-

Table 4. Milk production and composition, feed intake, and BW change of cows fed treatment diets containing either long- (19 mm) or shortcut $(10 \mathrm{~mm})$ orchardgrass silage as the sole source of forage

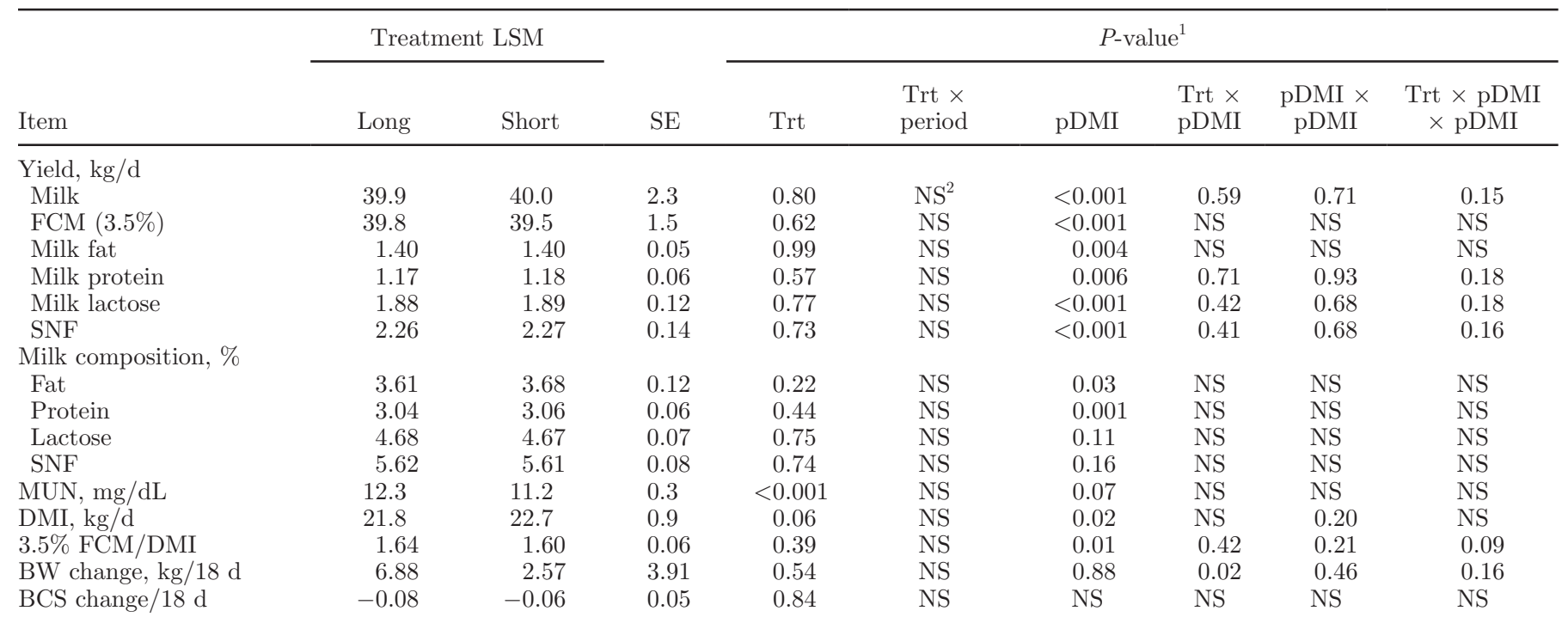

${ }^{1} P$-values for treatment (Trt), Trt by period interaction (Trt $\times$ period), preliminary DMI (pDMI), Trt by preliminary DMI interaction $($ Trt $\times$ $\mathrm{pDMI})$, quadratic effect of preliminary DMI $(\mathrm{pDMI} \times \mathrm{pDMI})$, and Trt by quadratic effect of preliminary DMI $($ Trt $\times \mathrm{pDMI} \times \mathrm{pDMI})$.

${ }^{2}$ Nonsignificant, with $P>0.20$; term was removed from the statistical model. 
ments. In both diets, forage NDF provided over $82 \%$ of the total diet NDF. Differences in DM concentration in diets were because of the different DM concentrations of the forages.

\section{Effects of Grass FPL and pDMI}

Forage particle length and its interaction with pDMI did not affect yields of milk or milk components or milk composition (Table 4). Long particles increased MUN concentrations $(P<0.001$; Table 4$)$ compared with short particles. This is consistent with higher ruminal ammonia concentration and flux of ammonia $\mathrm{N}$ to the duodenum $(P<0.01$; Table 5$)$ for long than short particles. Although long-cut OG silage was wetter, similar ammonia concentrations (Table 2) were measured in both silages and, therefore, long-cut OG silage was not the source for increased ammonia observed in cows fed long particles.

Long particles tended to increase starch ruminal rate of digestion (19.0 vs.14.9\%/h, $P=0.07$; Table 6) and true ruminal digestibility ( 60.3 vs. $49.8 \%, P=0.09$; Table 7) and tended to decrease starch flux from the rumen to the duodenum $(2.84$ vs. $3.51 \mathrm{~kg} / \mathrm{d}, P=0.09$;
Table 7) compared with short particles. The mechanism for increased starch digestion rate is unclear but one explanation is that longer forage particles may promote greater numbers or activity of starch-digesting bacteria in the rumens of cows consuming long particles. Some starch-digesting bacteria in the rumen (e.g., Streptococcus bovis) also have high proteolytic activity (Russell et al., 1981), resulting in deamination of amino acids and production of ammonia, which could contribute to the increased ammonia concentration for long particle-fed cows.

Long particles tended to decrease DMI (21.8 vs. 22.7 $\mathrm{kg} / \mathrm{d}, P=0.06$; Table 4) compared with short particles. We expected long particles to be more filling than short particles, causing greater rumen distention and potentially limiting DMI, particularly in cows with high DMI for which ruminal distention is more likely to limit feed intake (Allen, 1996). Oba and Allen (1999) and Voelker et al. (2002) found DMI responses varied by production level, which is generally correlated with DMI (NRC, 2001), where DMI was increasingly limited by high-fill diets compared with low-fill diets as milk yield increased. Although we expected the long-particle diet to slow rates of ruminal passage, FPL and its in-

Table 5. Nitrogen metabolism of cows fed treatment diets containing either long- $(19 \mathrm{~mm})$ or short-cut (10 mm) orchardgrass silage as the sole source of forage

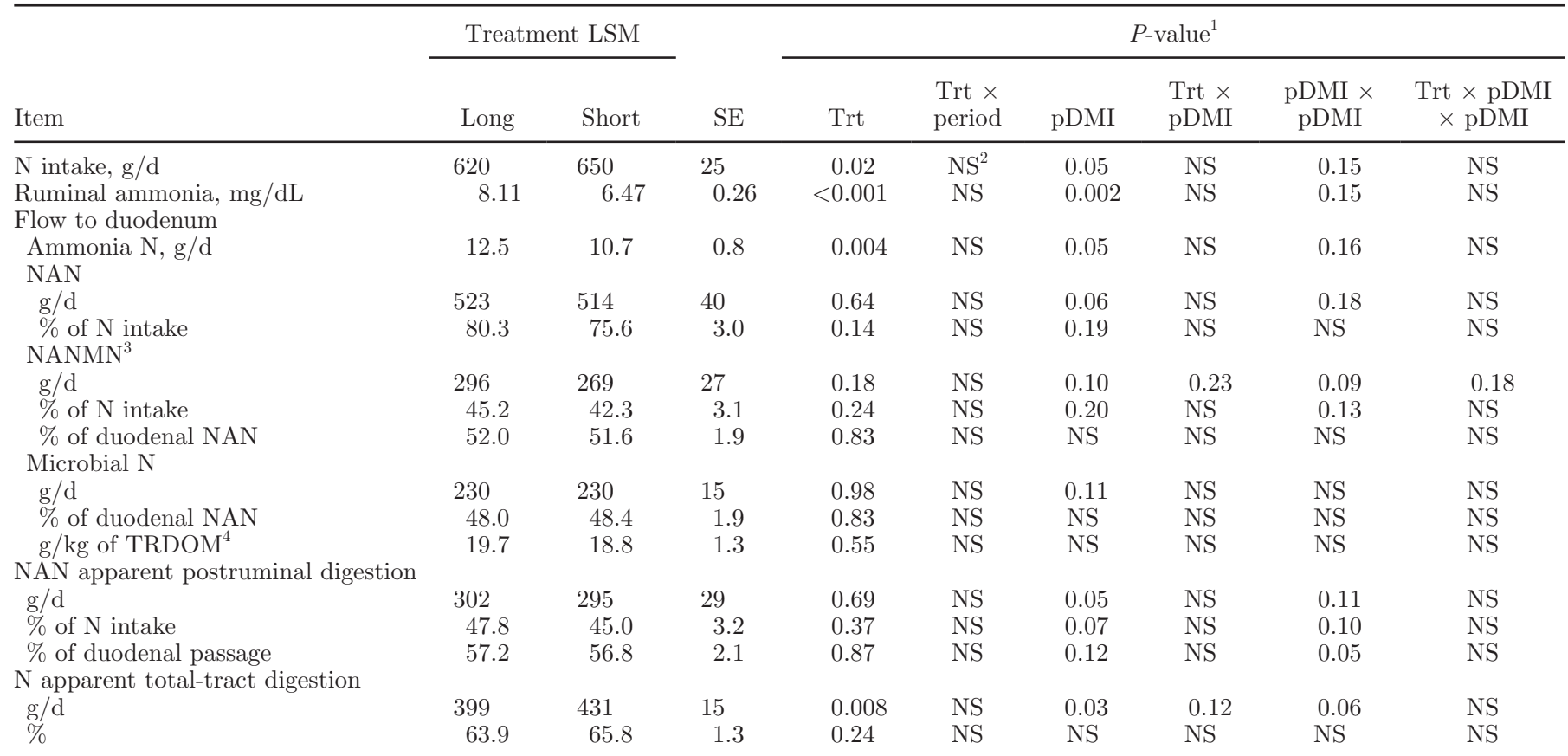

${ }^{1} P$-values for treatment $($ Trt $)$, Trt by period interaction $($ Trt $\times$ period), preliminary DMI $(\mathrm{pDMI})$, Trt by preliminary DMI interaction $($ Trt $\times$ $\mathrm{pDMI})$, quadratic effect of preliminary DMI $(\mathrm{pDMI} \times \mathrm{pDMI})$, and Trt by quadratic effect of preliminary DMI $($ Trt $\times \mathrm{pDMI} \times \mathrm{pDMI})$.

${ }^{2}$ Nonsignificant, with $P>0.20$; term was removed from the statistical model.

${ }^{3} \mathrm{NANMN}=$ nonammonia, nonmicrobial nitrogen.

${ }^{4} \mathrm{TRDOM}=$ true ruminally digested OM. 
Table 6. Rumen kinetics of cows fed treatment diets containing either long- $(19 \mathrm{~mm})$ or short-cut $(10 \mathrm{~mm})$ orchardgrass silage as the sole source of forage

\begin{tabular}{|c|c|c|c|c|c|c|c|c|c|}
\hline \multirow[b]{2}{*}{ Item } & \multicolumn{2}{|c|}{ Treatment LSM } & \multirow[b]{2}{*}{$\mathrm{SE}$} & \multicolumn{6}{|c|}{$P$-value ${ }^{1}$} \\
\hline & Long & Short & & Trt & $\begin{array}{l}\text { Trt } \times \\
\text { period }\end{array}$ & $\mathrm{pDMI}$ & $\begin{array}{l}\text { Trt } \times \\
\text { pDMI }\end{array}$ & $\begin{array}{c}\mathrm{pDMI} \times \\
\mathrm{pDMI}\end{array}$ & $\begin{array}{c}\text { Trt } \times \text { pDMI } \\
\times \text { pDMI }\end{array}$ \\
\hline \multicolumn{10}{|c|}{ Ruminal turnover rate, $\% / \mathrm{h}$} \\
\hline DM & 7.55 & 7.93 & 0.37 & 0.29 & $\mathrm{NS}^{2}$ & 0.34 & 0.11 & NS & NS \\
\hline $\mathrm{OM}$ & 7.62 & 8.03 & 0.39 & 0.27 & NS & 0.34 & 0.08 & NS & NS \\
\hline $\mathrm{NDF}$ & 4.40 & 4.44 & 0.22 & 0.83 & NS & 0.18 & 0.07 & NS & NS \\
\hline $\mathrm{pdNDF}^{3}$ & 7.31 & 7.04 & 0.36 & 0.48 & NS & 0.35 & 0.11 & NS & NS \\
\hline Starch & 32.9 & 31.0 & 2.6 & 0.49 & NS & 0.16 & 0.89 & 0.46 & 0.09 \\
\hline \multicolumn{10}{|c|}{ Ruminal turnover time, $\mathrm{h}$} \\
\hline DM & 13.6 & 13.0 & 0.6 & 0.32 & NS & 0.29 & 0.07 & NS & NS \\
\hline $\mathrm{OM}$ & 13.5 & 12.9 & 0.6 & 0.31 & NS & 0.28 & 0.05 & NS & NS \\
\hline NDF & 23.6 & 23.3 & 1.1 & 0.83 & NS & 0.14 & 0.05 & NS & NS \\
\hline pdNDF & 14.1 & 14.8 & 0.7 & 0.37 & NS & 0.28 & 0.13 & NS & NS \\
\hline iNDF $^{4}$ & 48.2 & 45.2 & 2.6 & 0.38 & NS & 0.08 & 0.09 & NS & NS \\
\hline Starch & 3.12 & 3.43 & 0.25 & 0.21 & NS & 0.29 & 0.85 & 0.48 & 0.06 \\
\hline \multicolumn{10}{|c|}{ Ruminal passage rate, $\% / \mathrm{h}$} \\
\hline pdNDF & 0.89 & 0.75 & 0.22 & 0.53 & NS & 0.12 & 0.45 & 0.45 & 0.19 \\
\hline iNDF & 2.23 & 2.29 & 0.13 & 0.70 & NS & 0.14 & NS & NS & NS \\
\hline Starch & 14.3 & 15.8 & 1.9 & 0.41 & NS & 0.50 & NS & 0.13 & NS \\
\hline \multicolumn{10}{|c|}{ Ruminal digestion rate, $\% / \mathrm{h}$} \\
\hline $\mathrm{pdNDF}$ & 6.63 & 6.28 & 0.29 & 0.38 & NS & 0.04 & 0.08 & NS & NS \\
\hline Starch & 19.0 & 14.9 & 1.8 & 0.07 & NS & 0.01 & 0.34 & 0.01 & 0.02 \\
\hline
\end{tabular}

${ }^{1} P$-values for treatment (Trt), Trt by period interaction (Trt $\times$ period), preliminary DMI (pDMI), Trt by preliminary DMI interaction $($ Trt $\times$ $\mathrm{pDMI})$, quadratic effect of preliminary DMI $(\mathrm{pDMI} \times \mathrm{pDMI})$, and Trt by quadratic effect of preliminary DMI $($ Trt $\times \mathrm{pDMI} \times \mathrm{pDMI})$.

${ }^{2}$ Nonsignificant, with $P>0.20$; term was removed from the statistical model.

${ }^{3} \mathrm{pdNDF}=$ potentially digestible NDF.

${ }^{4} \mathrm{iNDF}=$ indigestible NDF.

teraction with $\mathrm{pDMI}$ did not affect the rates of pdNDF, iNDF, or starch passed from the rumen (Table 6). However, the rate of ruminal digestion of pdNDF was related to $\mathrm{pDMI}$, which decreased at a faster rate for long particles than short particles as pDMI increased (interaction $P=0.08$; Figure $1 \mathrm{~A}$ ). As a result, long particles decreased or tended to decrease rates of ruminal turnover of pdNDF, NDF (interaction $P=0.07$; Figure 1B), OM, and DM (Table 6) and increased rumen pools of NDF (interaction $P=0.04$; Figure $1 \mathrm{C}$ ), OM, and

Table 7. Starch digestion of cows fed treatment diets containing either long- (19 mm) or short-cut (10 mm) orchardgrass silage as the sole source of forage

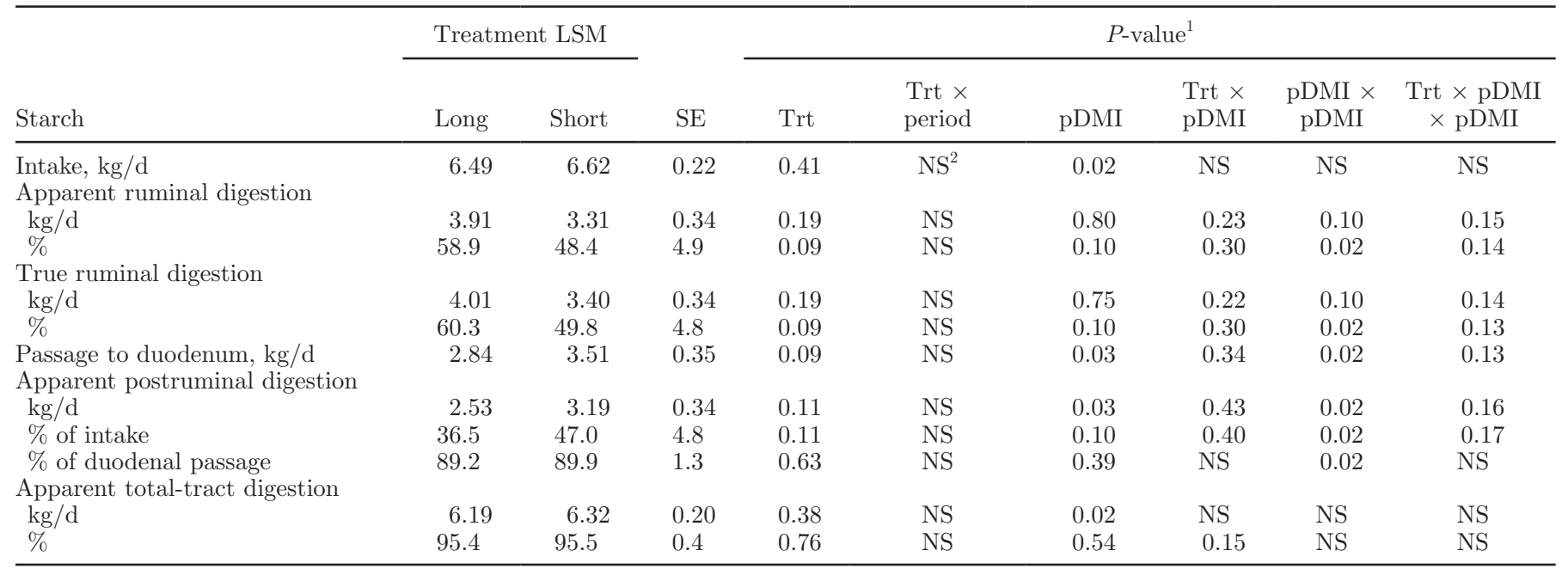

${ }^{1} P$-values for treatment $($ Trt $)$, Trt by period interaction $($ Trt $\times$ period), preliminary DMI $(\mathrm{pDMI})$, Trt by preliminary DMI interaction $($ Trt $\times$ $\mathrm{pDMI})$, quadratic effect of preliminary DMI $(\mathrm{pDMI} \times \mathrm{pDMI})$, and Trt by quadratic effect of preliminary DMI $($ Trt $\times \mathrm{pDMI} \times \mathrm{pDMI})$.

${ }^{2}$ Nonignificant, with $P>0.20$; term was removed from the statistical model. 
DM (Table 8) compared with short particles for cows with high pDMI, but effect of treatment on DMI was not related to $\mathrm{pDMI}$. Although the treatment by $\mathrm{pDMI}$ interaction was not significant (interaction $P>0.40$ ), a visual examination of a graph with $\mathrm{pDMI}$ and DMI (Figure 1D) illustrated the difference in DMI between long and short particles was small for cows with low pDMI but the difference became greater as pDMI increased, with the greatest divergence for cows with high pDMI. Therefore, rumen fill as a constraint limiting DMI for cows with high intake fed long particles compared with short particles is possible but results did not provide conclusive evidence.

Chewing activity results (Table 9) suggest that DMI for the long-particle diet was possibly limited by chewing time. Long particles increased meal length (39.1 vs. $33.0 \mathrm{~min} /$ bout, $P=0.008)$ and meal size ( 2.52 vs. $2.28 \mathrm{~kg}$ of $\mathrm{DM} /$ meal, $P=0.05)$, resulting in greater eating time (16.5 vs. $15.1 \mathrm{~min} / \mathrm{kg}$ of DMI, $P=0.02$ ) and ruminating time (25.4 vs. $23.2 \mathrm{~min} / \mathrm{kg}$ of DMI, $P$ $=0.05)$ and, thus, increased total chewing time $(42.0$ vs. $38.3 \mathrm{~min} / \mathrm{kg}$ of DMI and 867 vs. $827 \mathrm{~min} / \mathrm{d}, P=$ 0.02) compared with short particles. Long particles increased total time spent chewing to reduce particle size compared with short particles, but the effect of FPL on eating time was related to pDMI. Long particles increased and short particles decreased eating time [expressed as minutes per kilogram of DMI, minutes per kilogram of NDF intake (interaction $P=0.006$, Figure $1 \mathrm{E}$ ), and min per kilogram of forage NDF intake] as pDMI increased. Long particles increased eating time (expressed as min/d) with increasing pDMI compared with short particles, which remained constant for short particle-fed cows across the range of $\mathrm{pDMI}$ (interaction $P=0.004$; Figure 1F). Because the total amount of time spent chewing per day is likely limited (Van Soest, 1994), cows with high intake consuming long particles might have reached the upper limit for time spent chewing. In this study, long particle-fed cows had greater time chewing $($ mean $=867 \mathrm{~min} / \mathrm{d}$, ) compared with the mean chewing time $(694 \mathrm{~min} / \mathrm{d})$ across 72 treatments and 19 experiments (Tafaj et al., 2007), and total chewing time for individual cows ranged from 735 to 1,055 $\mathrm{min} / \mathrm{d}$. Cows consuming long particles spent $42 \mathrm{~min} /$ $\mathrm{kg}$ of $\mathrm{DM}$ and $152 \mathrm{~min} / \mathrm{kg}$ of NDF, which approached the maximum chewing time per unit of DM and NDF consumed (47 and $160 \mathrm{~min}$, respectively) reported by Tafaj et al. (2007).

Forage particle length and its interaction with pDMI did not affect ruminal $\mathrm{pH}$ (Table 10). We expected long particles to potentially increase ruminal $\mathrm{pH}$ through greater chewing and salivary buffer flow (Allen, 1997), but this was not observed. This might be because no main effects of treatment existed on rumen pool sizes
(Table 8), total rumination time (Table 9), or OM truly digested in the rumen (Table 11). Differences were detected for concentrations of VFA (Table 10), but these differences were quite small and likely not biologically significant.

Long particles decreased rumen empty BW for cows with pDMI $<26 \mathrm{~kg} / \mathrm{d}$ but increased BW for cows with pDMI $>26 \mathrm{~kg} / \mathrm{d}$ compared with short particles (interaction $P=0.02$; Table 4 ). The BW gain for long particle-fed cows with high pDMI occurred despite digesting less DM in total tract than short particle-fed cows (interaction $P=0.04$; Table 11). The reason for the BW changes observed in relation to FPL and pDMI is not clear.

Direct comparisons of animal responses across individual studies evaluating the effects of FPL should be interpreted with caution. Multiple reasons exist for this, which may help explain why results from particular experiments may or may not be in agreement. A wide range of FPL (2 to $32 \mathrm{~mm}$ ) has been reported for studies from 1997 to 2005 (Tafaj et al., 2007 ) and differences between FPL compared within studies (6 vs. $8 \mathrm{~mm}$, Yang and Beauchemin, 2004; 24 vs. $170 \mathrm{~mm}$, Randby et al., 2008). Furthermore, the lack of a consistent method of measuring and reporting physical characteristics complicates interpretation because similar TLC and physically effective NDF do not necessarily yield the same particle size distribution (Beauchemin and Rode, 1998). Responses to FPL vary depending on forage source, with greater differences reported for grass-based TMR compared with corn silage-based TMR (Tafaj et al., 2007). Additionally, feeding conditions differ, from offering forage and concentrate separately and limit fed (Zebeli et al., 2007) to numerous studies where cows are fed TMR ad libitum. Studies often evaluate the effect of FPL in combination with other dietary factors including, but not limited to, forage:concentrate ratio (Soita et al., 2000; Einarson et al., 2004), grain processing (Yang et al., 2001), grain fermentability (Krause and Combs, 2003), nonforage fiber sources (Mooney and Allen, 1997), and supplemental fat (Onetti et al., 2003).

\section{Effects of pDMI on Ruminal Passage Rates}

Experimental data on rates of passage from the rumen, particularly for individual feed fractions, are scarce. Given the effect of passage on ruminal digestion and microbial growth, quantitative knowledge on rates of nutrient passage from the rumen are needed to better understand nutrient availability in ruminants and improve nutrition models. Furthermore, because passage rates from the rumen generally increase with increased intake, measurements of ruminal passage rates 

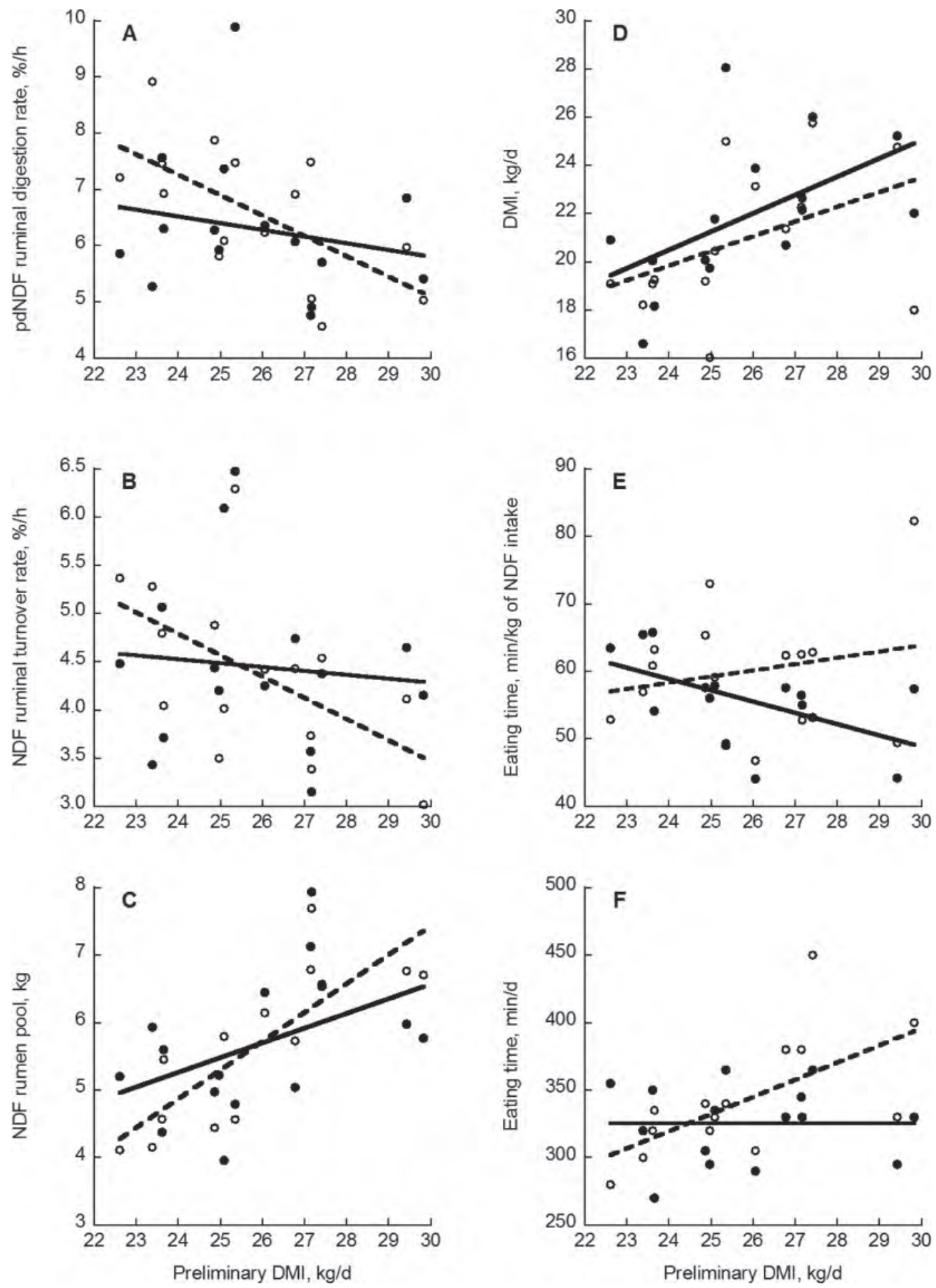

Figure 1. Interaction of long (19 mm; open circles, dashed line) and short (10 mm; closed circles, solid line) orchardgrass particle length with preliminary DMI for (A) potentially digestible NDF (pdNDF) ruminal digestion rate $(P=0.08),(\mathrm{B})$ NDF ruminal turnover rate $(P=0.07)$, (C) NDF rumen pool $(P=0.04)$, (D) DMI (interaction not significant), (E) eating time ( $\mathrm{min} / \mathrm{kg}$ of NDF intake; $P=0.006)$, and (F) eating time $(\mathrm{min} / \mathrm{d} ; P=0.004)$. The preliminary DMI on the $\mathrm{x}$-axis are the mean DMI of individual cows during the final $4 \mathrm{~d}$ of the preliminary period when all cows were fed a common diet. 
Table 8. Rumen pools of cows fed treatment diets containing either long- (19 mm) or short-cut (10 mm) orchardgrass silage as the sole source of forage

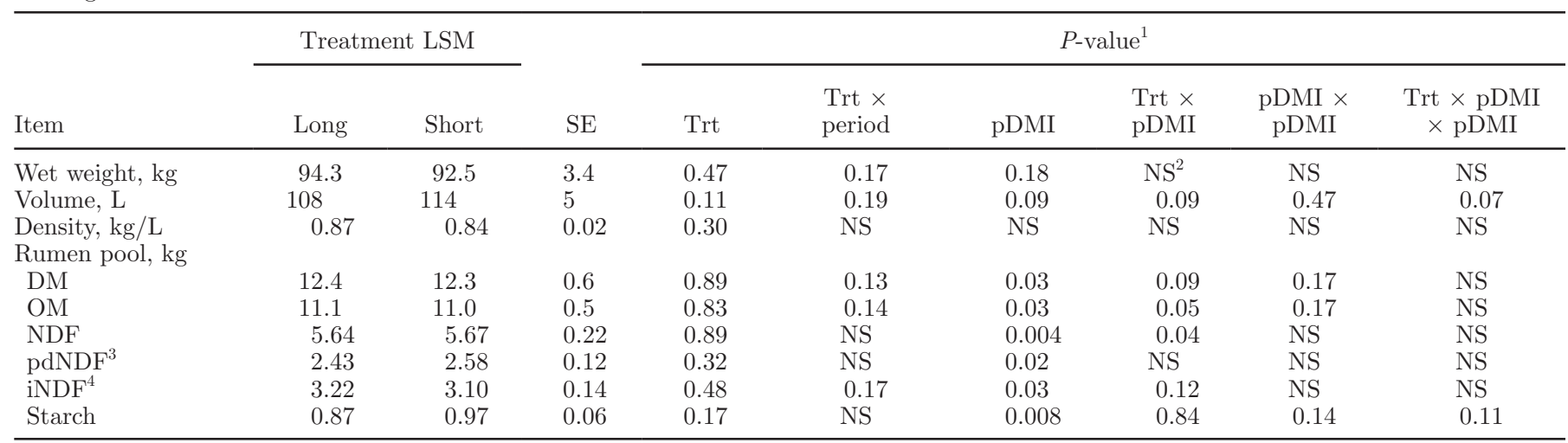

${ }^{1} P$-values for treatment $($ Trt $)$, Trt by period interaction $($ Trt $\times$ period), preliminary DMI (pDMI), Trt by preliminary DMI interaction $($ Trt $\times$ $\mathrm{pDMI})$, quadratic effect of preliminary DMI $(\mathrm{pDMI} \times \mathrm{pDMI})$, and Trt by quadratic effect of preliminary DMI $($ Trt $\times \mathrm{pDMI} \times \mathrm{pDMI})$

${ }^{2}$ Nonsignificant, with $P>0.20$; term was removed from the statistical model.

${ }^{3} \mathrm{pdNDF}=$ potentially digestible NDF.

${ }^{4} \mathrm{iNDF}=$ indigestible NDF.

Table 9. Chewing activity of cows fed treatment diets containing either long- (19 mm) or short-cut (10 mm) orchardgrass silage as the sole source of forage

\begin{tabular}{|c|c|c|c|c|c|c|c|c|c|}
\hline Item & \multicolumn{2}{|c|}{ Treatment LSM } & $\mathrm{SE}$ & \multicolumn{6}{|c|}{$P$-value ${ }^{1}$} \\
\hline Bouts/d & 9.28 & 10.2 & 0.67 & 0.13 & $\mathrm{NS}^{2}$ & 0.46 & 0.49 & 0.61 & 0.08 \\
\hline Length, $\min /$ bout & 39.1 & 33.0 & 2.3 & 0.008 & NS & 0.85 & 0.007 & 0.98 & 0.03 \\
\hline Interval, min & 138 & 123 & 10 & 0.14 & NS & 0.67 & 0.38 & 0.95 & 0.09 \\
\hline OM & 2.26 & 2.06 & 0.21 & 0.05 & NS & 0.51 & 0.58 & 0.70 & 0.01 \\
\hline NDF & 0.70 & 0.62 & 0.06 & 0.02 & NS & 0.57 & 0.50 & 0.65 & 0.01 \\
\hline $\mathrm{pdNDF}^{3}$ & 0.50 & 0.44 & 0.04 & 0.02 & NS & 0.55 & 0.62 & 0.64 & 0.01 \\
\hline $\mathrm{iNDF}^{4}$ & 0.20 & 0.17 & 0.02 & 0.04 & NS & 0.61 & 0.38 & 0.67 & 0.03 \\
\hline Starch & 0.78 & 0.69 & 0.07 & 0.03 & NS & 0.41 & 0.75 & 0.72 & 0.02 \\
\hline \multicolumn{10}{|l|}{ Eating time } \\
\hline $\operatorname{Min} / \mathrm{d}$ & 342 & 326 & 8 & 0.08 & NS & 0.08 & 0.004 & NS & NS \\
\hline \multicolumn{10}{|l|}{ Rumination } \\
\hline Length, min/bout & 36.8 & 34.3 & 1.4 & 0.06 & NS & NS & NS & NS & NS \\
\hline Interval, min & 55.1 & 57.3 & 3.6 & 0.43 & NS & 0.19 & 0.41 & 0.74 & 0.13 \\
\hline \multicolumn{10}{|l|}{ Ruminating time } \\
\hline $\operatorname{Min} / \mathrm{d}$ & 525 & 502 & 13 & 0.17 & NS & NS & NS & NS & NS \\
\hline $\mathrm{Min} / \mathrm{kg}$ of DMI & 25.4 & 23.2 & 0.8 & 0.05 & NS & 0.07 & NS & NS & NS \\
\hline $\mathrm{Min} / \mathrm{kg}$ of NDF intake & 92.0 & 86.1 & 3.1 & 0.12 & NS & 0.15 & NS & NS & NS \\
\hline Min/kg of forage NDF intake & 109 & 103 & 4 & 0.23 & NS & 0.06 & NS & NS & NS \\
\hline \multicolumn{10}{|l|}{ Total chewing time } \\
\hline $\operatorname{Min} / \mathrm{d}$ & 867 & 827 & 16 & 0.02 & NS & 0.16 & NS & NS & NS \\
\hline Min/kg of DMI & 42.0 & 38.3 & 1.2 & 0.02 & NS & 0.13 & NS & NS & NS \\
\hline Min $/ \mathrm{kg}$ of NDF intake & 152 & 142 & 5 & 0.04 & NS & NS & NS & NS & NS \\
\hline Min $/ \mathrm{kg}$ of forage NDF intake & 180 & 170 & 5 & 0.12 & NS & 0.10 & NS & NS & NS \\
\hline
\end{tabular}

${ }^{1} P$-values for treatment $($ Trt), Trt by period interaction (Trt $\times$ period), preliminary DMI (pDMI), Trt by preliminary DMI interaction $($ Trt $\times$ $\mathrm{pDMI})$, quadratic effect of preliminary DMI $(\mathrm{pDMI} \times \mathrm{pDMI})$, and Trt by quadratic effect of preliminary DMI $($ Trt $\times \mathrm{pDMI} \times \mathrm{pDMI})$.

${ }^{2}$ Nonsignificant, with $P>0.20$; term was removed from the statistical model.

${ }^{3} \mathrm{pdNDF}=$ potentially digestible NDF.

${ }^{4} \mathrm{iNDF}=$ indigestible NDF. 
Table 10. Ruminal VFA concentrations and $\mathrm{pH}$ of cows fed treatment diets containing either long- (19 mm) or short-cut (10 mm) orchardgrass silage as the sole source of forage

\begin{tabular}{|c|c|c|c|c|c|c|c|c|c|}
\hline \multirow[b]{2}{*}{ Item } & \multicolumn{2}{|c|}{ Treatment LSM } & \multirow[b]{2}{*}{$\mathrm{SE}$} & \multicolumn{6}{|c|}{$P$-value ${ }^{1}$} \\
\hline & Long & Short & & Trt & $\begin{array}{l}\text { Trt } \times \\
\text { period }\end{array}$ & $\mathrm{pDMI}$ & $\begin{array}{l}\text { Trt } \times \\
\text { pDMI }\end{array}$ & $\begin{array}{c}\mathrm{pDMI} \times \\
\mathrm{pDMI}\end{array}$ & $\begin{array}{c}\text { Trt } \times \text { pDMI } \\
\times \text { pDMI }\end{array}$ \\
\hline Acetate & 91.8 & 91.3 & 0.9 & 0.52 & NS & 0.02 & NS & NS & NS \\
\hline Propionate & 35.3 & 33.7 & 1.0 & 0.11 & NS & NS & NS & NS & NS \\
\hline Butyrate & 18.5 & 19.9 & 0.8 & 0.002 & NS & 0.92 & NS & 0.15 & NS \\
\hline Valerate & 1.87 & 1.91 & 0.07 & 0.32 & NS & 0.54 & NS & 0.19 & NS \\
\hline Isovalerate & 2.15 & 1.98 & 0.09 & 0.02 & NS & 0.36 & 0.78 & 0.39 & 0.07 \\
\hline Branched-chain VFA & 3.42 & 3.16 & 0.13 & 0.01 & NS & 0.41 & 0.32 & 0.51 & 0.05 \\
\hline Acetate:propionate & 2.62 & 2.74 & 0.06 & 0.09 & NS & 0.03 & 0.15 & NS & NS \\
\hline Ruminal pH & 5.84 & 5.84 & 0.03 & 0.88 & NS & NS & NS & NS & NS \\
\hline
\end{tabular}

${ }^{1} P$-values for treatment (Trt), Trt by period interaction (Trt $\times$ period), preliminary DMI (pDMI), Trt by preliminary DMI interaction $($ Trt $\times$ $\mathrm{pDMI})$, quadratic effect of preliminary DMI $(\mathrm{pDMI} \times \mathrm{pDMI})$, and Trt by quadratic effect of preliminary DMI $($ Trt $\times \mathrm{pDMI} \times \mathrm{pDMI})$.

${ }^{2}$ Nonsignificant, with $P>0.20$; term was removed from the statistical model.

of nutrients over a wide range of DMI are necessary. We measured the effects of DMI on rates of passage of nutrients from the rumen using the pool and flux method (Robinson et al, 1987).

Although we expected ruminal passage rates to increase with pDMI, passage rates of pdNDF, iNDF, and starch were not related to level of intake independent of or dependent upon treatment (Table 6). However, rate of starch digestion decreased quadratically (interaction
$P=0.02$; Figure $2 \mathrm{~A}$ ) and true ruminal digestibility of starch tended to decrease quadratically (interaction $P$ $=0.13$; Figure 2B) as pDMI increased. Two cows with high pDMI ( $>29 \mathrm{~kg}$ of $\mathrm{DM} / \mathrm{d})$ amplified the quadratic effects. The decreases in starch rate of digestion and digestibility are consistent with increased starch rumen pool (interaction $P=0.11$; Figure 2C) and likely related to the increased liquid dilution rate associated with increased intake (not measured), decreasing popu-

Table 11. Dry matter and OM digestion of cows fed treatment diets containing either long- (19 mm) or short-cut (10 mm) orchardgrass silage as the sole source of forage

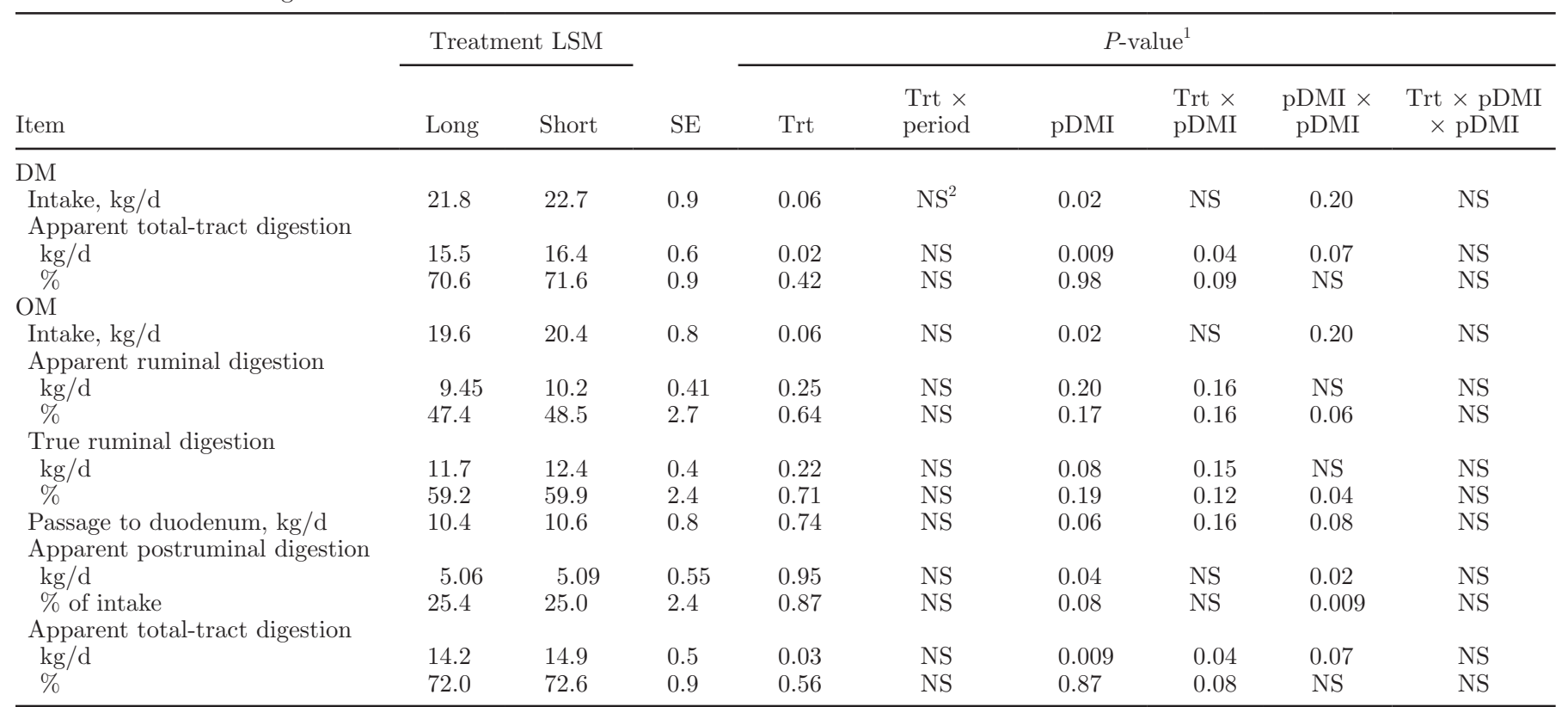

${ }^{1} P$-values for treatment $($ Trt $)$, Trt by period interaction (Trt $\times$ period), preliminary DMI $(\mathrm{pDMI})$, Trt by preliminary DMI interaction $($ Trt $\times$ $\mathrm{pDMI})$, quadratic effect of preliminary DMI $(\mathrm{pDMI} \times \mathrm{pDMI})$, and Trt by quadratic effect of preliminary DMI $($ Trt $\times \mathrm{pDMI} \times \mathrm{pDMI})$.

${ }^{2}$ Nonsignificant, with $P>0.20$; term was removed from the statistical model. 

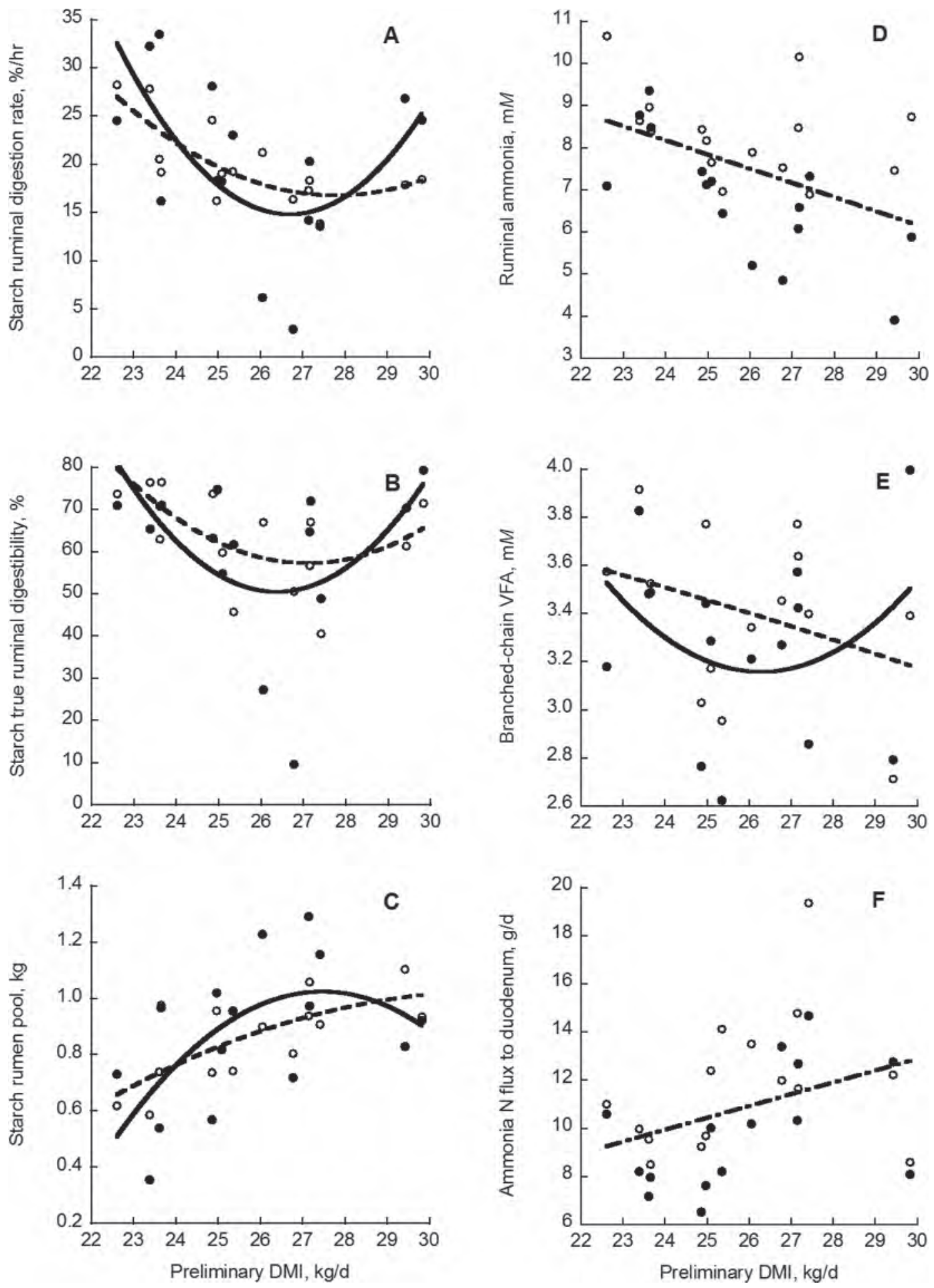

Figure 2. Relationship of long (19 mm; open circles, dashed line) and short (10 mm; closed circles, solid line) orchardgrass particle length with preliminary DMI for (A) starch ruminal digestion rate (interaction $P=0.02$ ), (B) starch true ruminal digestibility (interaction $P=0.13$ ), (C) starch rumen pool (interaction $P=0.11),(D)$ ruminal ammonia concentration $(P=0.002),(E)$ branched-chain VFA concentration (interaction $P=0.05)$, and $(\mathrm{F})$ ammonia $\mathrm{N}$ flux to duodenum $(P=0.05)$. The preliminary DMI on the $\mathrm{x}$-axis are the mean DMI of individual cows during the final $4 \mathrm{~d}$ of the preliminary period when all cows were fed a common diet. 

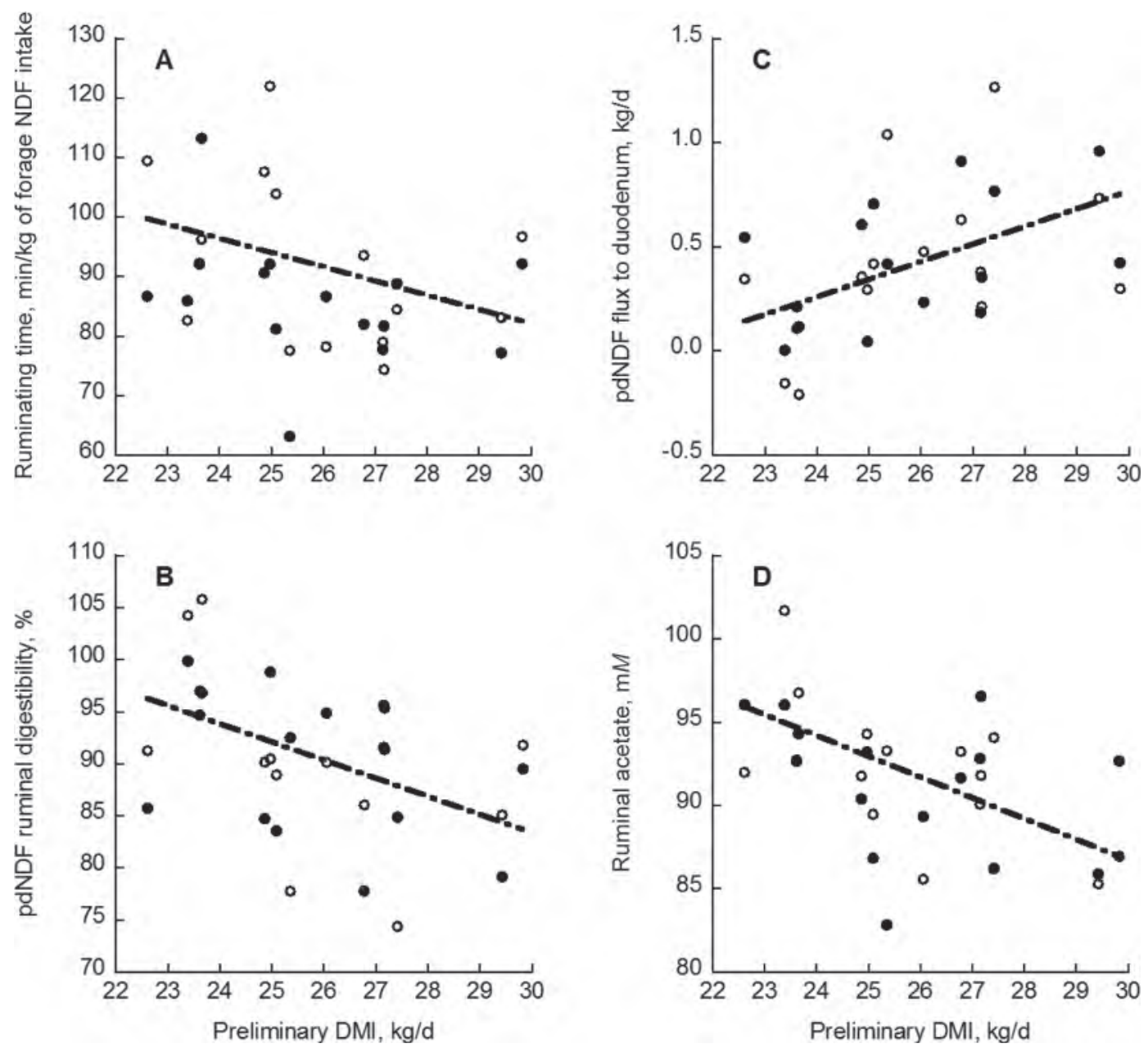

Figure 3. Relationship of long (19 $\mathrm{mm}$; open circles) and short (10 mm; closed circles) orchardgrass particle length with preliminary DMI for (A) ruminating time per unit of forage $\operatorname{NDF}(P=0.06),(B)$ potentially digestible NDF (pdNDF) ruminal digestibility $(P=0.07),(\mathrm{C})$ pdNDF flux to duodenum $(P=0.05)$, and $(\mathrm{D})$ ruminal acetate concentration $(P=0.02)$. The preliminary DMI on the $\mathrm{x}$-axis are the mean DMI of individual cows during the final $4 \mathrm{~d}$ of the preliminary period when all cows were fed a common diet.

lations of starch-digesting microbes. Concentrations of ruminal ammonia $(P=0.002$; Figure $2 \mathrm{D})$ and branchchained VFA (interaction $P=0.05$; Figure $2 \mathrm{E}$ ), which are derived from degradation of branched-chain amino acids, also decreased with increased pDMI and are consistent with less proteolytic activity in the rumen due to greater removal of ruminal microbes through passage and lysis. As pDMI increased, ammonia $\mathrm{N}$ flux to the duodenum $(P=0.05$; Figure $2 \mathrm{~F})$ increased and MUN concentration $(P=0.07$; Table 4$)$ tended to increase.

Additionally, the rate of pdNDF digestion decreased as pDMI increased and had a greater effect on long than short particles (interaction $P=0.08$; Figure 1A), as previously mentioned. The decrease in pdNDF digestion rate is likely related to differences in mechanical processing (TLC) and mastication, which reduce particle size and increase the surface area available for microbial attachment and enzymatic attack (Bowman and Firkins, 1993). The proportion of large particles in the rumen increases with higher DMI (Okine and Mathison, 1991) because ruminating time per unit of DM consumed decreases as DMI increases (Welch and Smith, 1969). In this experiment, cows tended to decrease amount of time spent ruminating per unit of forage NDF consumed as level of intake increased $(P=$ 0.06 ; Figure $3 \mathrm{~A})$. As a result of the decrease in pdNDF digestion rate, cows tended to decrease ruminal pdNDF digestibility (\%,P $=0.07$; Figure 3B) and increased pdNDF flux from the rumen to the duodenum $(P=$ 0.05; Figure 3C) as pDMI increased (Table 12). Furthermore, ruminal acetate concentration decreased as pDMI increased $(P=0.02$; Figure $3 \mathrm{D})$, which is con- 
Table 12. NDF digestion of cows fed treatment diets containing either long- (19 mm) or short-cut (10 mm) orchardgrass silage as the sole source of forage

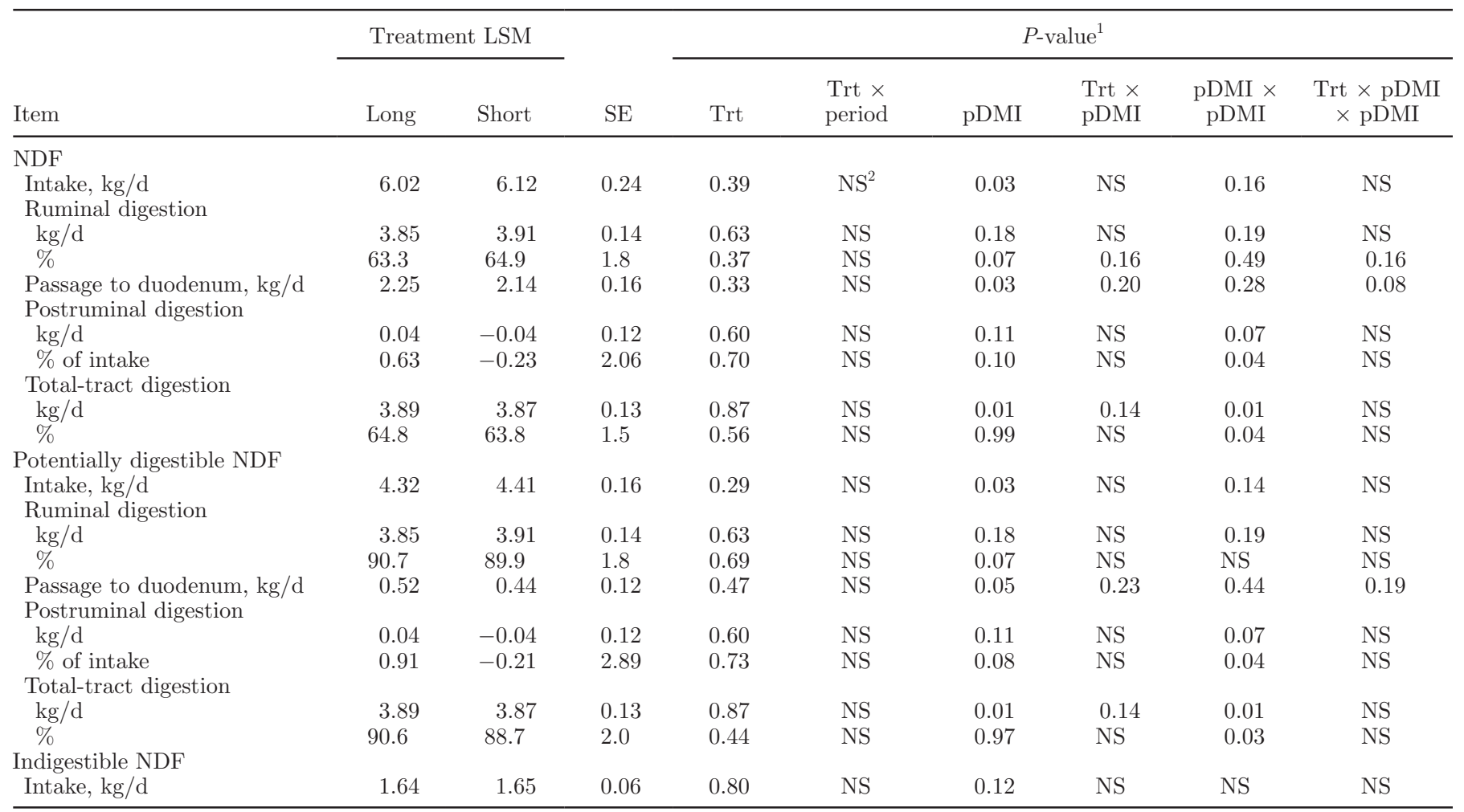

${ }^{1} P$-values for treatment (Trt), Trt by period interaction (Trt $\times$ period), preliminary DMI (pDMI), Trt by preliminary DMI interaction $($ Trt $\times$ $\mathrm{pDMI})$, quadratic effect of preliminary DMI $(\mathrm{pDMI} \times \mathrm{pDMI})$, and Trt by quadratic effect of preliminary DMI $($ Trt $\times \mathrm{pDMI} \times \mathrm{pDMI})$.

${ }^{2}$ Nonsignificant, with $P>0.20$; term was removed from the statistical model.

sistent with lower ruminal pdNDF digestibility because acetate is the predominant VFA produced from fiber digestion.

\section{Effects of pDMI on N Flux and Microbial Efficiency}

Fluxes of NAN and NANMN from the rumen to the duodenum tended to increase as pDMI increased, which increased or tended to increase postruminal NAN digestion $(\mathrm{g} / \mathrm{d})$ and digestibility (\%) with increased pDMI $(P \leq 0.10$; Table 5). Microbial $\mathrm{N}$ flux and efficiency (gram of MN produced per kilogram of true ruminally digested $\mathrm{OM}$ ) were not related to level of intake (Table 5 ) or quantity of OM truly digested in the rumen (not shown). However, a positive relationship was observed between microbial efficiency and ruminal passage rates of starch $\left(P<0.001, \mathrm{R}^{2}=0.44 ;\right.$ Figure $\left.4 \mathrm{~A}\right)$ and pdNDF $\left(P<0.001, \mathrm{R}^{2}=0.52 ;\right.$ Figure $\left.4 \mathrm{~B}\right)$. This indicated that energy from ruminal fermentation was more efficiently utilized for microbial growth as passage rates for starch and pdNDF increased, and the greater passage rates possibly decreased microbial lysis and turnover in the rumen because many microbial organisms flow from the rumen attached to fibrous particles.
Microbial N flux and efficiency are low for both treatments in the present experiment. This is unlikely associated with the method used because this same method was used in other experiments that reported higher MN flux and efficiency (Oba and Allen, 2003b; Taylor and Allen, 2005). Microbial N flux has not been consistent among studies comparing orchardgrass and alfalfa with MN flux ranging from low (Voelker Linton and Allen, 2009) to high (K. L. Kammes and M. S. Allen, unpublished data). This indicates low microbial yield is not specific to OG. The reason for low MN production in this study is not clear but appears to be related to the treatments.

\section{CONCLUSIONS}

Grass particle length and its interaction with pDMI did not affect milk yield, milk composition, or rumen $\mathrm{pH}$. Increasing grass particle length tended to decrease DMI, which might be limited by rumen fill or chewing time, or both. Passage rates of feed fractions did not differ between long and short particles and were not related to level of intake. As pDMI increased, long particles decreased ruminal digestion rate of pdNDF 

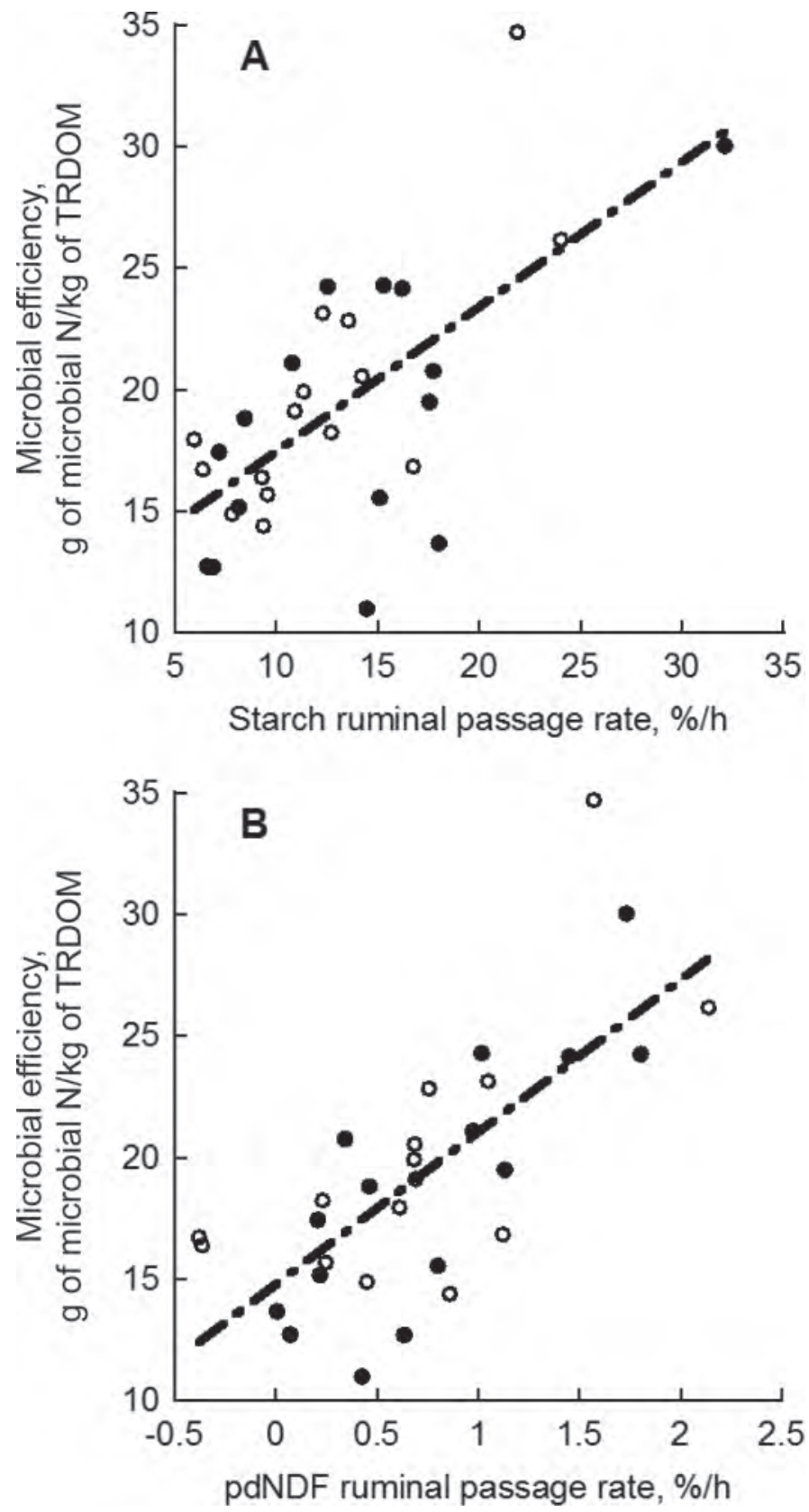

Figure 4. (A) Relationship between starch ruminal passage rate and microbial efficiency. Microbial efficiency [ $\mathrm{g}$ of microbial $\mathrm{N} / \mathrm{kg}$ of true ruminally digested $\mathrm{OM}(\mathrm{TRDOM})]=11.5+0.595 \times$ starch ruminal passage rate $\left(\% / \mathrm{h} ; P<0.001, \mathrm{R}^{2}=0.44\right)$. (B) Relationship between potentially digestible NDF (pdNDF) ruminal passage rate and microbial efficiency. Microbial efficiency ( $\mathrm{g}$ of microbial $\mathrm{N} / \mathrm{kg}$ of TRDOM $)=14.8+6.26 \times$ pdNDF ruminal passage rate $(\% / \mathrm{h} ; P<$ $\left.0.001, \mathrm{R}^{2}=0.52\right)$. Open circles denote long $(19 \mathrm{~mm})$ and closed circles denote short $(10 \mathrm{~mm})$ orchardgrass particle length. Starch and pdNDF ruminal passage rates were also positively correlated $\left(P<0.001, \mathrm{R}^{2}\right.$ $=0.43$, not shown).

at a faster rate than did short particles. As a result, long particles decreased or tended to decrease rates of ruminal turnover for NDF, OM, and DM and increased their rumen pools compared with short particles for cows with high pDMI. Long particles increased eating time, which affected cows with high intake to the greatest extent, and total chewing time compared with short particles. Ruminal starch digestibility decreased, starch rumen pool increased, and postruminal starch digestibility increased quadratically as feed intake increased. Sorting of feed particles was minimal in this experiment due to the wet forages and individual feeding of cows, but sorting would likely increase for cows fed diets using drier forages or group fed. When grass silage was the only source of forage in the diet, increasing chop length from 10 to $19 \mathrm{~mm}$ tended to decrease DMI but did not negatively affect productivity of cows, which were fed adequate fiber.

\section{ACKNOWLEDGMENTS}

This project was supported by National Research Initiative Competitive Grant no. 2006-35206-16708 from the USDA National Institute of Food and Agriculture. The authors thank N. K. Ames for performing duodenal and ruminal cannulations; laboratory technicians D. G. Main, R. A. Longuski, and Y. Ying; R. E. Kreft and the staff of the Michigan State University Dairy Cattle Teaching and Research Center (East Lansing) for their technical assistance and support, Barenbrug USA (Tangent, OR) for their donation of Baridana orchardgrass seed, and West Central Soy Cooperative (Ralston, IA) for donating the SoyPLUS protein supplement.

\section{REFERENCES}

Allen, M. S. 1996. Physical constraints on voluntary intake of forages by ruminants. J. Anim. Sci. 74:3063-3075.

Allen, M. S. 1997. Relationship between fermentation acid production in the rumen and the requirement for physically effective fiber. J. Dairy Sci. 80:1447-1462.

Allen, M. S., and D. R. Mertens. 1988. Evaluating constraints of fiber digestion by rumen microbes. J. Nutr. 118:261-270.

Beauchemin, K. A., and L. M. Rode. 1998. Effective fibre in barleybased diets. Adv. Dairy Technol. 10:151-165.

Bowman, J. G. P., and J. L. Firkins. 1993. Effects of forage species and particle size on bacterial cellulolytic activity and colonization in situ. J. Anim. Sci. 71:1623-1633.

Broderick, G. A., and J. H. Kang. 1980. Automated simultaneous determination of ammonia and total amino acids in rumen fluid and in vitro media. J. Dairy Sci. 63:64-75.

Cochran, R. C., D. C. Adams, J. D. Wallace, and M. L. Galyean. 1986. Predicting digestibility of different diets with internal markers: Evaluation of four potential markers. J. Anim. Sci. 63:1476-1483.

Dado, R. G., and M. S. Allen. 1994. Variation in and relationships among feeding, chewing, and drinking variables for lactating dairy cows. J. Dairy Sci. 77:132-144.

Dixon, R. M., and L. P. Milligan. 1985. Removal of digesta components from the rumen of steers determined by sieving techniques and fluid, particulate and microbial markers. Br. J. Nutr. 53:347-362.

Einarson, M. S., J. C. Plaizier, and K. M. Wittenberg. 2004. Effects of barley silage chop length on productivity and rumen conditions of lactating dairy cows fed total mixed ration. J. Dairy Sci. 87:2987-2996.

Goering, H. K., and P. J. Van Soest. 1970. Forage Fiber Analysis (Apparatus, Reagents, Procedures, and Some Applications). Agric. Handbook No. 379. USDA-ARS, Washington, DC. 
Grant, R. J. 1997. Interactions among forages and nonforage fiber sources. J. Dairy Sci. 80:1438-1446.

Hach, C. C., B. K. Bowden, A. B. Kopelove, and S. V. Brayton. 1987. More powerful peroxide Kjeldahl digestion method. J. Assoc. Off. Anal. Chem. 70:783-787.

Heinrichs, J. 1996. Evaluating particle size of forages and TMRs using the Penn State Particle Size Separator. Technical Bulletin of The Pennsylvania State University, College of Agricultural Sciences, Cooperative Extension. DAS 96-20. Department of Dairy and Animal Science, The Pennsylvania State University, University Park.

Joy, M. T., E. J. DePeters, J. G. Fadel, and R. A. Zinn. 1997. Effects of corn processing on the site and extent of digestion in lactating cows. J. Dairy Sci. 80:2087-2097.

Karkalas, J. 1985. An improved enzymatic method for the determination of native and modified starch. J. Sci. Food Agric. 36:10191027.

Krause, K. M., and D. K. Combs. 2003. Effects of forage particle size, forage source, and grain fermentability on performance and ruminal pH in midlactation cows. J. Dairy Sci. 86:1382-1397.

Kung, L., and R. Shaver. 2001. Interpretation and use of silage fermentation analysis reports. University of Wisconsin Extension Publ. Series. Focus on Forage 3:1-5. College of Agricultural \& Life Sciences, University of Wisconsin-Madison.

Lammers, B. P., D. R. Buckmaster, and A. J. Heinrichs. 1996. A simplified method for the analysis of particle sizes of forage and total mixed rations. J. Dairy Sci. 79:922-928.

Mertens, D. R. 2002. Gravimetric determination of amylase-treated neutral detergent fiber in feeds using refluxing in beakers or crucibles: Collaborative study. J. AOAC Int. 85:1217-1240.

Mooney, C. S., and M. S. Allen. 1997. Physical effectiveness of the neutral detergent fiber of whole linted cottonseed relative to that of alfalfa silage at two lengths of cut. J. Dairy Sci. 80:2052-2061.

NRC. 2001. Nutrient Requirements of Dairy Cattle. 7th rev. ed. Natl. Acad. Sci., Washington, DC.

Oba, M., and M. S. Allen. 1999. Effects of brown midrib 3 mutation in corn silage on dry matter intake and productivity of high yielding dairy cows. J. Dairy Sci. 82:135-142.

Oba, M., and M. S. Allen. 2003a. Effects of corn grain conservation method on feeding behavior and productivity of lactating dairy cows at two dietary starch concentrations. J. Dairy Sci. 86:174183.

Oba, M., and M. S. Allen. 2003b. Effects of diet fermentability on efficiency of microbial nitrogen production in lactating dairy cows. J. Dairy Sci. 86:195-207.

Okine, E. K., and G. W. Mathison. 1991. Effects of feed intake on particle distribution, passage of digesta, and extent of digestion in the gastrointestinal tract of cattle. J. Anim. Sci. 69:3435-3445.

Onetti, S. G., R. D. Shaver, S. J. Bertics, and R. R. Grummer. 2003 Influence of corn silage particle length on the performance of lactating dairy cows fed supplemental tallow. J. Dairy Sci. 86:2949 2957.

Randby, Å. T., T. Garmo, M. Eknæs, and E. Prestløkken. 2008. Effect of grass silage chop length on intake and milk production by dairy cows. Grassl. Sci. Europe 13:768-770.

Robinson, P. J., S. Tamminga, and A. M. van Vuuren. 1987. Influence of declining level of feed intake and varying proportion of starch in the concentrate on rumen ingesta quantity, composition and kinetics of ingesta turnover in dairy cows. Livest. Prod. Sci. 17:37-62.

Robles, A. Y., R. L. Belyea, F. A. Martz, and M. F. Weiss. 1980. Effect of particle size upon digestible cell wall and rate of in vitro digestion of alfalfa and orchard grass forages. J. Anim. Sci. 51:783-790.

Russell, J. B., W. G. Bottje, and M. A. Cotta. 1981. Degradation of protein by mixed cultures of rumen bacteria: Identification of Streptococcus bovis as an actively proteolytic rumen bacterium. J. Anim. Sci. 53:242-252.

Smith, L. W. H. K. Goering, and C. H. Gordon. 1972. Relationships of forage compositions with rates of cell wall digestion and indigestibility of cell walls. J. Dairy Sci. 55:1140-1147.

Soita, H. W., D. A. Christensen, and J. J. McKinnon. 2000. Influence of particle size on the effectiveness of the fiber in barley silage. J. Dairy Sci. 83:2295-2300.

Tafaj, M., Q. Zebeli, Ch. Baes, H. Steingass, and W. Drochner. 2007. A meta-analysis examining effects of particle size of total mixed rations on intake, rumen digestion and milk production in highyielding dairy cows in early lactation. Anim. Feed Sci. Technol. 138:137-161

Taylor, C. C., and M. S. Allen. 2005. Corn grain endosperm type and brown midrib 3 corn silage: Ruminal fermentation and N partitioning in lactating cows. J. Dairy Sci. 88:1434-1442.

Van Soest, P. J. 1994. Nutritional Ecology of the Ruminant. 2nd ed. Cornell University Press, Ithaca, NY.

Voelker, J. A., G. M. Burato, and M. S. Allen. 2002. Effect of pretrial milk yield on responses of feed intake, digestion, and production to dietary forage concentration. J. Dairy Sci. 85:2650-2661.

Voelker Linton, J. A., and M. S. Allen. 2008. Nutrient demand interacts with forage family to affect intake and digestion responses in dairy cows. J. Dairy Sci. 91:2694-2701.

Voelker Linton, J. A., and M. S. Allen. 2009. Nutrient demand interacts with forage family to affect nitrogen digestion and utilization responses in dairy cows. J. Dairy Sci. 92:1594-1602.

Welch, J. G., and A. M. Smith. 1969. Effect of varying amounts of forage intake on rumination. J. Anim. Sci. 28:827-830.

Wildman, E. E., G. M. Jones, P. E. Wagner, R. L. Boman, H. F. Troutt Jr., and T. N. Lesch. 1982. A dairy cow body condition scoring system and its relationship to selected production characteristics. J. Dairy Sci. 65:495-501.

Yang, W. Z., and K. A. Beauchemin. 2004. Grain processing, forageto-concentrate ratio, and forage length effects on ruminal nitrogen degradation and flows of amino acids to the duodenum. J. Dairy Sci. 87:2578-2590.

Yang, W. Z., K. A. Beauchemin, and M. L. Rode. 2001. Effects of grain processing, forage to concentrate ratio, and forage particle size on rumen $\mathrm{pH}$ and digestion in dairy cows. J. Dairy Sci. 84:2203-2216.

Zebeli, Q., M. Tafaj, I. Weber, J. Dijkstra, H. Steingass, and W. Drochner. 2007. Effects of varying dietary forage particle size in two concentrate levels on chewing activity, ruminal mat characteristics, and passage in dairy cows. J. Dairy Sci. 90:1929-1942.

Zinn, R. A., and F. N. Owens. 1986. A rapid procedure for purine measurement and its use for estimating net ruminal protein synthesis. Can. J. Anim. Sci. 66:157-166. 